\title{
The changing influence of societal culture on job satisfaction across Europe
}

Article

Accepted Version

Pacheco, G., van der Westhuizen, D. W., Ghobadian, A., Webber, D. J. and O'Regan, N. (2016) The changing influence of societal culture on job satisfaction across Europe. British Journal of Management. ISSN 1045-3172 doi: https://doi.org/10.1111/1467-8551.12150 Available at https://centaur.reading.ac.uk/62845/

It is advisable to refer to the publisher's version if you intend to cite from the work. See Guidance on citing.

Published version at: http://dx.doi.org/10.1111/1467-8551.12150

To link to this article DOI: http://dx.doi.org/10.1111/1467-8551.12150

Publisher: Wiley

All outputs in CentAUR are protected by Intellectual Property Rights law, including copyright law. Copyright and IPR is retained by the creators or other copyright holders. Terms and conditions for use of this material are defined in the End User Agreement.

\section{www.reading.ac.uk/centaur}

\section{CentAUR}

Central Archive at the University of Reading 
Reading's research outputs online 
The Changing Influence of Societal Culture on Job Satisfaction Across Europe

\section{Gail Pacheco}

Faculty of Business \& Law, AUT, Private Bag 92006, Auckland 1142, NZ gail.pacheco@aut.ac.nz

\section{De Wet van der Westhuizen}

Faculty of Business \& Law, AUT, Private Bag 92006, Auckland 1142, NZ dwvander@aut.ac.nz

Abby Ghobadian*

Henley Business School, University of Reading Henley-on-Thames, RG9 3AU, Oxfordshire, UK abby.ghobadian@henely.ac.uk

Don J. Webber

Bristol Business School, Coldharbour Lane, Bristol BS16 1QYE

Don.Webber@uwe.ac.uk

\section{Nicholas O'Regan}

Bristol Business School, Coldharbour Lane, Bristol BS16 1QYE

Mail: Nicholas.O'Regan@uwe.ac.uk

*Corresponding author 


\section{The Changing Influence of Societal Culture on}

\section{Job Satisfaction Across Europe}

\section{Abstract}

We contribute to the growing multidisciplinary body of literature on subjective well-being by investigating the longitudinal stability and impact of societal cultural values (SCVs) - as opposed to the more common organisational values on job satisfaction. It is assumed that SCVs evolve slowly; hence, their impact on job satisfaction is likely to remain stable over time. False adherence to this assumption could cause misalignment between organisational policies/practices and expectations formed by societal culture, decreasing job satisfaction and adversely effecting productivity, competiveness and prosperity. We use four waves of the European Values Study to examine whether SCVs have evolved and their impacts on job satisfaction over a relatively short time period: 1981 to 2008 .

We parameterise SCVs through reference to traditional vs secularrational, and survival vs self-expression value continuums. Results indicate that the strength of many SCVs has declined, the impacts of traditional societal values on job satisfaction have remained fairly constant and the impacts of survival societal values on job satisfaction have declined substantially over this sample period. These reductions in SCVs amplify the importance of accounting for such changes when designing new or adjusting existing policies/practices to enhance job satisfaction and stimulate improvements in productivity, competitiveness and prosperity. 
Culture and Job Satisfaction

Keywords: societal culture, job satisfaction, traditional values, survival values, productivity, competitiveness. 



\section{Introduction}

Employers can achieve higher productivity and greater returns from their workforces by enhancing job satisfaction, capitalising on greater motivation levels and mitigating the effects of withdrawal behaviours and attitudes. The extant literature points to a close link between job satisfaction and productivity (Miller and Monge, 1986; DuBrin, 1991), a critical determinant of competitiveness (Husband and Ghobadian, 1981; Muellbauer, 1986, 1991) and prosperity (Bernolak, 1997; Lee and Tang, 2000). Job satisfaction is a popular research topic due to its pervasive nature and multi-layered impact.

Although the current body of research aimed at identifying determinants of job satisfaction is of undoubted value (e.g. Gaspay et al., 2008), the influence of societal culture - a pervasive and critical external force that shapes the values and beliefs of individuals - on job satisfaction has been largely overlooked. This is of concern from both theoretical and practical perspectives. The dominant theory suggests that societal culture is time invariant; hence, the assumption of neutral impact on job satisfaction. If false, adherence could result in misalignment between firms' policies/practices and employee expectations shaped by societal culture, adversely affecting job satisfaction and consequently lower productivity, reduced competitiveness and declining prosperity. Significant changes in the external environment, e.g., globalisation, increased cross-border labour movement, and changes to the retirement age, further test the stability theory. Coyle-Shapiro and Shore (2007) postulated that major external environmental changes speed up the evolution of societal cultural values (SCV), altering the relationship between the organisation and its employees and affecting employees' responses to an organisation's policies and practices. If true, then managers face a challenge.

Societal culture is commonly defined as a system of shared values, beliefs and behavioural norms, which are learned and passed from one generation to the next through the 
laws, policies and actions of a society (Aycan et al., 2000; Thomas et al., 2010). Oyserman (2001) suggests that cultural identities are not formed in isolation, but within a broader set of social values, norms and beliefs, which are shared with others within that context. SCVs underlie people's attitudes and behaviour (Sengupta and Sinha, 2005). They help individuals to establish priorities (Miller et al., 1990), determine right from wrong, or desirable from undesirable behaviour (Ball-Rokeach, 1973) and make sense of situations they encounter (Fiske and Taylor, 1991). This paper explores the longitudinal evolution of SCVs , testing their time invariance, and assessing changes in their impacts on job satisfaction across Europe over the period 1981 to 2008 . As a by-product we also examine the relationship between job satisfaction and socio-demographic factors and work-related characteristics over three decades.

Organisations are open systems interacting with formal and informal institutions (Daft, 2007). Societal culture is among the key informal institutions (North, 1990). Researchers have examined attempts by multinational enterprises to account for SCV differences across their foreign subsidiaries (Luthans, 1993; Wasti, 1998). Other studies have shown that SCV impacts the: motivation of public service employees (Ritz and Brewer, 2013); performance appraisal practices (Peretz and Fried, 2012), reward alignment (Magnusson et al., 2014), success of exploratory innovations (Muller et al., 2013) and employee-organisation relationships (Fitzsimmons and Stamper, 2014). Other studies have examined the job-life satisfaction balance using SCVs (Georgellis and Lange, 2012).

Empirical studies examining the link between SCVs and job satisfaction are less common. Arguably this line of research has been hampered by the subjective nature of the two concepts, as well as the scarcity of appropriate data measuring SCVs. Although these issues are omnipresent, progress has been made in effectively measuring a range of cultural values that shape a society's cultural identity (Inglehart and Baker, 2000; Inglehart, 2006) 
through the use of cross-country data sets, e.g., the European Values Study (EVS, 2014). Such progress has led to empirical investigations demonstrating link between SCVs and job satisfaction (Hui et al., 1995; Huang and Van de Vliert, 2004; Fargher et al., 2008; Lange, 2009; Van der Westhuizen et al., 2012). Although these studies provide valuable snap shots, there is a paucity of longitudinal empirical research examining this relationship and, as pointed out, this is an important gap.

The aim of this paper is to empirically examine the: (i) longitudinal stability of SCVs; (ii) effect of SCVs on job satisfaction; (iii) the longitudinal relationship between SCVs and job satisfaction. Societal culture is parameterised by following the approach of Inglehart and Baker (2000). Additionally, all four waves of EVS are incorporated in this study facilitating comparisons to be made over the period 1981 to 2008 . The study offers organisations the potential of better understanding the importance of accounting for the likely evolution of SCVs when adjusting or developing policies as alignment could lead to higher levels of job satisfaction, boosting productivity, competitiveness and prosperity.

The rest of the paper is structured as follows. In the next section we review the pertinent literature and offer key theoretical insights. This is followed by a discussion of data and methodology. We finish with a discussion of key conclusions and implications for theory and practice. 


\section{Literature review and theory}

Job satisfaction

Although extensively researched, much debate surrounds the meaning of job satisfaction. At the centre of this debate is the question of whether job satisfaction is determined by the characteristics of the job itself, within the mind of the employee, or through the interaction of the employee and their job (Locke, 1969). Through addressing such questions, Locke (1969, p. 316) defines job satisfaction as 'the pleasurable emotional state resulting from the appraisal of one's job as achieving or facilitating the achievement of one's job values'. In the context of this definition, Locke (1969, p. 320) defines values as that which an individual 'actually seeks to gain and/or keep or considers beneficial'. His work also addresses value hierarchies, suggesting that individuals rank their values by importance and that ultimately individuals 'value some things more than others' (Locke, 1969, p. 328). Based on these definitions, it can be postulated that job satisfaction is a function of the perceived relationship between what an employee seeks to gain from their job and what the employee perceives their job to offer, as well as the relative importance of the value (Locke, 1969). The scope of this paper does not extend to a further development of Locke's (1969) theory; rather, it is well placed to empirically explore the following: (i) whether what one seeks to gain and/or keep, or considers beneficial as part of one's job, is influenced by societal culture, and (ii) whether SCV hierarchies remain constant over time (i.e. do individuals rate the relative importance of certain values consistently over an extended time period?).

On an empirical level, job satisfaction has become one of the most widely studied areas in organisational research due to its pervasive nature and multilayered impact; e.g. , the growing awareness of its relationship with withdrawal behaviours, such as absenteeism, lateness and drug abuse (Saari and Judge, 2004) and lower levels of productivity (Miller and Monge, 1986; DuBrin, 1991). Work by Hoppock (1937) and Kerr (1948) laid the foundations 
for a flourishing multidisciplinary pursuit. Research continues towards identifying determinants of job satisfaction covering socio-demographic variables (e.g. gender, age and educational level), domain-specific variables such as dispositional influences (e.g. personality traits; see Judge and Bono, 2001), work situational influences (e.g. job challenge, being acknowledged; see Kovach, 1995), organisational policies (e.g. reward, performance management ; see Fletcher and Williams, 1996; Mason, 1997; Helm, 2013; Saridakis et al., 2013) and organisational capabilities (see Chiva and Alegre, 2009). Such empirical research is of immense value from an organisational perspective, informing the development of policies aimed at fostering higher levels of job satisfaction or assessing the value of policies.

Another stream of research has examined the relationship between organisational culture and job satisfaction. For example, job satisfaction has been shown to be positively related to organisational cultures characterised by clan and adhocracy typologies (Lund, 2003) as well as organisational cultures promoting fairness and opportunities for growth (Bellou, 2010). The next subsection explores culture in more detail.

\section{What is culture?}

Despite a plethora of empirical research supporting the link between organisational culture and individual values and behaviour (Taylor et al., 2008; Riggle et al., 2009; Bellou, 2010) linking this to how SCVs can affect individual behaviour within an organisational setting has largely been neglected. Research on this front was initiated by Hofstede (1980) when he introduced a national cultural framework encompassing 50 countries in two survey rounds between 1967 and 1973 (Yamamura et al., 2003). Within this framework, a set of cultural dimensions were developed to characterise the concept of national culture, ${ }^{1}$ which was defined as 'the collective programming of the mind that distinguished the members of one group or category of people from other' (Hofstede, 1980, p. 25). 
Central to this framework is the argument that culture is like one's mental software, considerably stable in nature and a reliable predictor of how individuals within society are likely to think and act (Hofstede, 1991, 2001); this view is shared by others (e.g. Child, 1981; Hitt et al., 2012). The 'stable' theory is based on the premise that the established institutions reinforce the societal norms and the ecological conditions that led to them (Hofstede, 2001, p. 12). There is limited empirical supportfor this proposition (Smith et al., 1996). Stable theory assumes that, SCVs can be viewed as a homeostatic quasi-equilibrium (Gaspay et al., 2008) leading to the hypothesis that SCVS have a stable influence on job satisfaction over time.

In contrast, some perceive societal culture as being more dynamic. For instance, Myers and Tan (2002) hold that culture is continually being reinvented and is in a constant state of flux, while Jones and Alony (2007) suggest that more research is needed to capture shifting cultural maps caused by globalisation. It is also argued that people are now operating within at least two national-based frames of cultural reference because of the homogenising effect of globalisation (Hewling, 2005) and potentially, due to the continuous exposure to new cultures, past cultural identities may have become diluted and ultimately reinvented.

The need for evidence to corroborate, or otherwise, these two contrasting theories is becoming increasingly pertinent, particularly as increasing globalisation, multiculturalism, and multigenerationalism disrupt societal cultural equilibria. Additionally, the assumption that institutions are immune from change, and act to reinforce societal norms and ecological conditions, is questioned (Lawrence et al., 2002). These points are supported by other scholars (Hewling, 2005; Jones and Alony, 2007). At the very least it is important to test this theoretical perspective empirically; hence our research is a timely contribution to both theory and practice. 
Our findings will provide the basis for more robust time-sensitive organisational strategies aimed at keeping a close alignment between organisational policies and evolving societal culture.

Concern has been raised regarding Hofstede's (1980) approach, as it largely refers to work values and whether work values provide a good indication of national culture (Georgellis and Lange, 2012). Nonetheless, Georgellis and Lange (2012) concede that 'culture' has been measured and applied in a number of contexts, including individual, organisational as well as national. When discussing the connection between cultural differences and multinational businesses, Ghemawat and Reiche (2011) state that crosscultural misunderstandings and cultural differences, while difficult to observe and measure, are very important for multinational businesses because culture influences the attitudes and behaviours of employees and a failure to appreciate and account for cultural differences can lead to embarrassing blunders, strained relationships and lower performance. Accordingly, the literature has established links between cultural distance and (i) cross-border debt and equity foreign portfolio investments (Aggarwal et al., 2009), (ii) foreign direct investment (Benassy-Quere et al., 2005) and (iii) mergers and acquisitions (Wong, 2007).

Supporting the notion that culture is open to change, Inglehart (2006) and Inglehart and Baker (2000) associated shifts in societal culture with economic development. Within this cultural change, however, a significant degree of persistence of traditional values is often observed. This persistence, along with the variation in cultural values among industrialised societies, can be attributed to differences in cultural heritage, and particularly to religious heritage. To this point, Hofstede and Hofstede (2005) acknowledge that self-expression of $\mathrm{SCVs}-$ e.g., visible cultural practices such as symbols (e.g. words or gestures) or rituals (e.g. practices or activities) - are formed later in life and are more susceptible to change under alternative cultural environments. Traditional values are implicit and are typically held 
unconsciously, passed down through the generations as parents instil the same values into their children as they had instilled into themselves by their parents (Hofstede et al., 2010). Hence, traditional values are unlikely to change over time or by relocating to a region with different SCVs. This leads us to propose two hypotheses related to cultural values:

H1a: Traditional SCVs are more likely to remain static over time.

H1b: Self-expression SCVs are more likely to vary over time.

\section{Culture and job satisfaction}

Theorising the exact nature of the relationship between SCVs and job satisfaction is a difficult task. Deresky (2011) as well as Browaeys and Price (2008) discuss how effective managers and particularly those in multinational organisations must be very aware of societal cultural differences. In an empirical investigation into the job-life satisfaction relationship across Europe, Georgellis and Lange (2012) concluded that the relationship between job-life satisfaction varies across societies and that those variations are related to SCVs. They further caution against the assumption that managerial theories - e.g., Maslow's (1970) needgratification - are universally applicable. This implies that SCVs may moderate the effect of various management inputs on employee outcomes, including job satisfaction. There is a range of explanations as to why such moderation takes place. For instance, it is theorised that an individual's SCVs can affect their expectations of various aspects of their job (Hui, 1990; Probst and Lawler, 2006). If reality exceeds their expectations, a higher level of job satisfaction is most likely to result, and vice versa. For example, certain SCVs, such as individualism as opposed to collectivism, may lead an individual desiring self-directed and autonomous tasks in their job (Oyserman et al., 2002). If an employer increases the level of autonomy for a set of employees, it would be expected that the job satisfaction of those employees who hold individualistic SCVs will increase by a greater proportion than those who do not hold such values. 
An alternative, but not necessarily opposing, theory suggests that SCVs may influence the level of resistance that individuals have in the face of various management initiatives (Kirkman and Shapiro, 1997, 2001). For example, SCVs that lead an individual to have a greater aversion to collaborating with others and relying on other team members will be more likely to resist changes that push for greater team-based work. On the other hand, other SCVs may lead an individual to resist management initiatives that result in greater selfmanagement. Attitudinal outcomes, such as lower commitment and lower job satisfaction, are ways in which individuals manifest their resistance (Kotter and Schlesinger, 1979). Our second aim therefore is to test whether cultural values affect job satisfaction at the individual level.

\section{Existing studies}

Contributions to the parameterisation and influence of SCVs on job satisfaction include Hui et al. (1995), Huang and Van de Vliert (2004), Moutafi et al. (2007), Fargher et al. (2008), Lange (2009) and Van der Westhuizen et al. (2012). The effects of SCVs on participatory decision-making (PDM) and job satisfaction across Europe were empirically explored by Van der Westhuizen et al. (2012), whose analysis of the survival/self-expression continuum suggests that movements towards traditional values resulted in higher levels of job satisfaction while movements towards survival values yielded the opposite effect. Additionally, it was found that both traditional and self-expression values resulted in higher levels of PDM, and that this impact was more significant for women, with respect to the selfexpression domain. Lange (2009) illustrated how a legacy constructed on Communist industrial relations in Central and Eastern Europe influences job satisfaction, even after economic and social transitions have occurred. In a comparative study, Fargher et al. (2008) investigated the effects of SCVs on job satisfaction between Eastern and Western Europe 
concluding that traditional values were more imbedded in Western European culture, playing a more influential role in job satisfaction for this region. An indirect link is also drawn by Moutafi et al. (2007) suggesting SCVs act as a moderating factor between job performance and extroversion/introversion, with extroverts being more satisfied in their jobs than introverts (Rahim, 1981). Similarly Furnam and Springfield (1993) studied middle and senior management in an Asian-based international airline and found that extroversion correlated with high job performance for European managers whereas introversion was positively associated with job success for Chinese managers.

Taking a different approach, Huang and Van de Vliert (2004) found that job level was positively correlated with job satisfaction in countries with individualistic SCVs but had no effect in countries with collectivistic SCVs. Individualistic cultural values promote welfare, interests and goals of the individual and his/her core family (Sagie and Aycan, 2003), while collectivistic cultural values are those that advocate membership within communities or large groups and consider the welfare, interests and goals of the group to be more important than those of the individual group member (Sagie and Aycan, 2003). In contrast, Hui et al. (1995) found that collectivistic employees reported a higher level of satisfaction with their work and other job-related variables (e.g. pay, promotion, co-workers) than their individualistic counterparts. This result was consistent even after accounting for the different ranks of employees.

Therefore the body of research reviewed suggests that there is a link between SCVs and job satisfaction. However, current research primarily relies on snapshots rather than longitudinal data. Moreover, the previous research does not implicitly examine possible differences between traditional and self-expression SCVs and the direction of the relationship is not straightforward. Our third aim is therefore to contribute to the literature by 
investigating culture changes over time and whether the effect of culture on job satisfaction changes over time.

According to the literature some SCVs are more susceptible to change than others. Inglehart (2006) and Inglehart and Baker (2000) emphasise traditional vs secular-rational and survival vs self-expression dimensions of SCVs, and although their theory has come under some scrutiny (Haller, 2002), it has served as the basis of several empirical investigations relating to the influence of SCVs on behavioural outcomes (see Dalton et al., 2002; Oosterbeek et al., 2004; Fargher et al., 2008; Van der Westhuizen et al., 2012). These variables cover both traditional and self-expression SCVs enabling us to test the theoretical argument proffered previously. Furthermore, a range of variables that are available in all four waves of the EVS fit into these two dimensions, as will be discussed in the next section. A key feature of this study is that it investigates the link between SCVs, representing both traditional and self-expression values, and job satisfaction over time, thereby gauging the influence of SCVs on job satisfaction over three decades, a missing piece in the existing empirical literature.

Taking our lead from Fitzsimmons and Stamper (2014) we posit that at an individual level SCVs shape what employees seek to achieve from their jobs and, through variation in the self-concept, their perception of what their job offers - hence, their job satisfaction. This theoretical argument is supported by other scholars (Scott and Lane, 2000). We further posit that, based on Locke (1969), the importance attached to 'value' is a key determinant of job satisfaction. Moreover, based on the arguments presented, the influence of the traditional elements of SCVs on job satisfaction are likely to remain static over the short to medium term, while the influence of self-expression elements of SCVs on job satisfaction are likely to vary over the short to medium term. These arguments result in two additional hypotheses that the following empirical investigation will test: 
H2a: Traditional cultural values have a static influence on job satisfaction over time.

H2b: Self-expression cultural values have a dynamic influence on job satisfaction over time.

\section{Data and methodology}

Data

We use data from the EVS: a cross-national survey on basic human values, which provides insights into the ideas, beliefs, preferences, attitudes, values and opinions of citizens from across Europe. Our sample comes from all four currently available waves (1981, 1990, 1999 and 2008) and provides the best opportunity of conducting a longitudinal analysis. The majority of the existing literature tends to use only the most recent two waves; however, future research could take advantage of the next wave, available in 2017. The sample is restricted to the countries that were included in all four waves to provide a consistent data source. Our sample is also restricted to those respondents who were employed, of working age (18 to 64) and not self-employed. This yielded an effective sample of 17,600 respondents. It is important to recognise that while these SCV / attitudes are based on individual data, they can also be linked to the $n$th level, as the predominant set of values (whether traditional or self-expression) often help form societal cultural identity. Table 1 presents the percentage of respondents by country, for the 2008 survey it shows a higher job satisfaction rating in Denmark (7.96), Iceland (8.31) and Ireland (8.10).

\section{$<$ Insert Table $1>$}

Job satisfaction is a self-reported ordinal variable on a scale of 1 to 10 , with 1 representing 'complete dissatisfaction' and 10 corresponding to 'complete satisfaction' with the respondent's job. Job satisfaction relative to the country average is used as the dependent variable in the empirical analysis, to control for country-specific influences in our 
estimations. We also adjust standard errors in the empirical analysis to allow for the clustering of respondents within the 13 participating countries.

Using a single item job satisfaction variable to capture the multidimensional nature of the concept may be problematic, as we cannot distinguish between the extrinsic (e.g. instrumental, material) aspects of employment such as promotion, pay or job security, and the intrinsic (e.g. quality of work) aspects such as relations with managers, scope for initiative and the nature of the work itself. Acknowledging this concern, we take comfort from research by Wanous et al. (1997), which suggests that workers' satisfaction can be adequately examined on the basis of a single-item measurement. Further research (once more suitable data is available) should explore whether the use of single-item measurements for job satisfaction affect the subsequent statistical relationships identified here. To test the robustness of our subsequent results, we also re-estimated the empirical models using z-score transformations (which take into account the variable's standard deviation) of the job satisfaction variable.

Table 2 provides descriptive statistics of all explanatory variables used in our empirical analysis. These include a range of socio-demographic characteristics (e.g. gender, age, marital status and household income), work-related characteristics (e.g. occupational status, job values) and cultural values of the individual.

\section{$<$ Insert Table 2 >}

We focus on the two main dimensions of societal culture grounded on research by Inglehart (2006) and Inglehart and Baker (2000): (i) traditional vs. secular-rational and (ii) survival vs self-expression values. Traditional societies tend to emphasise religion, the family unit, absolute moral standards and deference to authority, while secular-rational values emphasise the opposite. In terms of the latter dimension, societies ranking highly with regard to survival values are found to prioritise economic and physical security above all else, which 
leads to insistence on traditional gender roles, low levels of interpersonal trust, intolerance of others and an emphasis on hard work, while self-expression values favour the opposite. A range of variables was selected from EVS to capture these two distinct societal cultural spectrums (see Table 2).

We follow work by Inglehart and Baker (2000) and create the dimensions of traditional vs secular-rational and survival vs self-expression values. A key emphasis of traditional vs secular-rational values is religion. In this study, we follow previous empirical work by Draulans and Halman (2005), Halman and Draulans (2006) and Knutsen (2009) by using 'believes in hell' as a measure of differences in religious beliefs.

Figure 1 portrays the mean values of the societal cultural variables for the core set of countries present across all four EVS waves. In contrast to all the other cultural variables that are dummy in nature, 'divorce is never justifiable' and 'homosexuality is never justifiable' are categorical and ordered from 1 to 10 , and are therefore placed on the secondary axes in the two plots shown in Figure 1. With respect to the traditional cultural values, all except 'believes in hell' follow a downward trend in our core countries sample. Most noticeably, "confidence in church"2 has experienced a substantial drop between the third and fourth wave of EVS. The decline in the mean for 'confidence in church' is not surprising given that the social importance of religion has generally decreased across Europe (Voicu, 2009). Furthermore, with beliefs (including those of a religious nature) being commonly prescribed by the church and practices of the local community (Halman and Draulans, 2004), and urbanisation breaking local community ties allowing individuals to adjust their belief systems (Voicu, 2009), one would expect fewer people to report confidence in religious institutions (i.e. the church).

\section{$<$ Insert Figure $1>$}


In a similar fashion, all five indicators of survival variables have decreased in importance over the sample period. Two variables are particularly prominent: 'homosexuality is never justifiable' became increasingly justifiable and 'tolerance and respect are unimportant to teach at home' experienced a remarkable increase (i.e. intolerance fell) between the first and second wave. These observations are in line with existing literature, which finds that self-expressive values have increased in importance over recent decades within industrialised societies (Inglehart and Baker, 2000; Inglehart, 2006). Hofstede et al. (2010) also acknowledge that national wealth is associated with increasing levels of individualism, which is itself a close equivalent of the self-expression measure (Inglehart, 2006).

Both Figure 1 and Table 2 lend support to H1b (self-expression SCVs are more likely to vary over time) but go against H1a (traditional SCVs are likely to remain static over time). In terms of the latter, these findings are unexpected, as they indicate that apart from 'Believes in Hell,' all other indicators for traditional SCVs have experienced a downward trend over the sample period.

While this descriptive portrait provides insight into the general trends of cultural values across Europe over time, more complex econometric work is required to extract the impact of these values on job satisfaction, while holding constant other potential confounding factors.

\section{Empirical approach}

Given the categorical and ordinal nature of the job satisfaction variable, $J S$, an appropriate empirical estimation approach to apply to identify the determinants of job satisfaction is ordered logit regression. The general form of the ordered logit model is:

$J S_{i}=\beta X_{i}^{\prime}+u_{i} \quad i=1,2, \ldots, N$ 
with the ordered response, $J S$, having ten categories. The ordered response model is defined as:

$$
\begin{aligned}
& \operatorname{Pr}(J S=j \mid X, \alpha, \beta)=F_{j}\left(\alpha_{j}-X^{\prime} \beta\right)-F_{j-1}\left(\alpha_{j-1}-X^{\prime} \beta\right) \\
& \quad \text { where } j=1,2, \ldots 10, \quad \alpha_{0}=-\infty, \quad \alpha_{j-1} \leq \alpha_{j}, \quad \alpha_{m}=\infty \quad \text { and } F \text { is the cumulative }
\end{aligned}
$$

distribution function of the logit distribution $F_{j}=1 /\left(1+\exp \left(-\left(\alpha_{j}-X^{\prime} \beta\right)\right)\right)$. The underlying job satisfaction equation for estimation is:

$$
\begin{aligned}
J S=\alpha & +\beta^{*} \text { Culture }+\beta^{*} \text { Job values }+\beta^{*} \text { Job level }+\beta^{*} \text { Gender }+\beta^{*} \text { Age } \\
& +\beta^{*} \text { Marital status }+\beta^{*} \text { Employment characteristics }+\beta^{*} \text { Household income }+u
\end{aligned}
$$

We doubt that individuals are independently and identically distributed across the sample and instead expect individual characteristics to have higher correlations if they are from the same country. Thus in the empirical analysis we control for country-specific influences by incorporating country-level clustering into our regression approach. This may have its limitations, as it requires the assumption that job satisfaction and all of other variables have a strong degree of similarity within each country. Future researchers ought to test the veracity of this assumption in countries where prima facia there are cultural difference between communities, e.g., Walloon and Flemish in Belgium.

Additionally, to ensure that the occurrence of multicollinearity was minimised in the regression analysis, all cultural variables were orthogonalised using Draper and Smith's (1981) orthogonalisation process. For the traditional variables, this is done with respect to the 'confidence in church' indicator; and for the survival values, this is done with respect to the 'homosexuality is never justifiable' variable. This process ensures that each of the societal cultural variables are contributing a unique aspect within their own societal cultural value domain, and are not related to the other societal cultural variables within their own societal value domain. 


\section{Results}

Examination of the societal cultural variables above highlights some important trends. However, a more sophisticated empirical approach is required in order to identify whether SCVs influence job satisfaction. The results of our ordered logit regression are provided in Table 3.

\section{$<$ Insert Table $3>$}

Three model variants were employed for each of the four waves of EVS. The first model includes only socio-demographic characteristics as determinants of job satisfaction; the second augments this model with work-related characteristics; while the third augments it further to include SCVs based on the two dimensions of traditional vs secular-rational and survival vs self-expression.

Our early model suggests that males are more satisfied at work relative to their female counterparts (e.g. Model I in 1990 and 1999) but this impact changes sign when work-related characteristics are included. The finding that men are less satisfied at work, on average, relative to females, corresponds to findings by Fargher et al. (2008) who made use of just the third wave of EVS.

Apart from 1981, the results support a U-shaped relationship between 'age' and job satisfaction. Clark et al. (1996) link this empirical observation to an individual's personal circumstances over their life stages and non-work related factors that impact on job satisfaction. This also provides support to value hierarchies (Locke, 1969), whereby the relative importance of certain values might change over an individual's life. The effect of marital status on job satisfaction is generally positive if the worker is married, though this impact is not always statistically significant. Once we have taken account of the fullest range of explanatory variables (i.e. Model III) then we find that it is only in 1999 that being married had a significant positive impact on job satisfaction. 
Based on the results of Model I, the impact of household income on job satisfaction shows that belonging to a medium- or high-income household had a positive impact on job satisfaction, relative to belonging to a low-income household, which could be indicative of the types of jobs held by higher income individuals who may have more control or 'voice' in their job, and hence find it more satisfying. However, in 1999 and 2008, these estimated coefficients turn negative once work-related characteristics are included (i.e. Models II and III). This result may be due to workers from higher income households having higher expectations than those from lower income households, and once work-related factors such as occupational status and other work attitudes are controlled for, the impact on job satisfaction is negative, as these expectations are not being met. This reasoning may also help to explain why the impact of belonging to a higher income household was still positive (albeit statistically insignificant) prior to 1990 , even after controlling for work-related characteristics; expectations of what you receive from your job in terms of utility may have been lower three decades ago or they may have become artificially inflated over time, and hence these expectations were easier to meet and exceed in wave 1 , relative to subsequent waves of EVS.

It would have been useful to add education to the group of socio-demographic characteristics in Table 3, as it is often expected to play a key part in determining job satisfaction. However, in order to ensure consistency across our specifications in all four waves it was necessary to exclude educational qualifications as an explanatory variable because data were not collected as part of the survey in waves 1 and 2 of EVS. While this is an important limitation, we draw comfort from the fact that other recent studies, such as Fargher et al. (2008), did not find a statistically significant impact of medium educational attainment (relative to low levels of education) across the whole European sample in their study of wave 3 , and only found a significant impact of high educational attainment on job 
satisfaction for males from Western Europe. Additionally, we would expect to indirectly capture educational attainment through the use of occupational status indicators (professional, skilled, less skilled and manual), which many past empirical studies, such as Fargher et al. (2008), did not employ in their specifications.

With respect to work-related characteristics, the impact of PDM on job satisfaction stands out. Having the freedom to be part of the decision-making process appears to be a key determinant of satisfaction at work, and this result is unchanged when societal cultural characteristics are added to the specification (i.e. Model II to III). This finding validates recent empirical research by Van der Westhuizen et al. (2012), which shows a similar result for wave 4 of the EVS. The findings also indicate that this impact appears to be timeinvariant over the 1981 to 2008 period.

Within the set of work values, if an individual perceives that 'good pay' is an important job characteristic then they are less likely to be satisfied at work. The same result holds for 'good hours'. It is likely that those who indicate that either 'good pay' and/or 'good hours' are important are those who are not happy with their pay and/or hours, and hence this is a possible reason why they are less satisfied at work. 'Job security' appears to have had a decreasing impact on job satisfaction over time; it was significant at the $1 \%$ level in 1981, as well as in Model II in 1990, and significant at the 10\% level in Model II in 1999, and insignificant by 2008 .

\section{Societal cultural values}

Our attention now turns to our core set of independent variables. For the first set of SCVs, those from the traditional vs secular-rational perspective, the results from the ordered logit regression (Table 4) generally support the notion that the influence of SCVs on job satisfaction remains stable over time. In particular, two variables stand out: (i) 'confidence in 
church' and (ii) 'always love and respect one's parents'. Both variables have statistically significant positive impacts on job satisfaction in all four waves. ${ }^{2}$

$<$ Insert Table 4 >

Although the preliminary analysis of mean values in Figure 1 indicated that there has been an overall decline in 'confidence in church', with a substantial drop between the third (1999/2000) and fourth (2008) wave of EVS, the results of the ordered logit regression portrays that, in general, having 'confidence in church' does have a positive influence on a respondent's job satisfaction and this influence has remained relatively stable between 1981 and 2008. The odds ratios indicate that having 'confidence in church' results in an individual being $11.4 \%$ more likely to move up one category of job satisfaction in 1981 , and this figure steadily increases to $18.8 \%$ by 2008 .

Such findings provide credence to Inglehart and Baker's (2000) notion that even though church attendance has dwindled to the point where only a small number attend church services regularly, religious traditions have shaped societal culture through institutions, such as the church, to a point where those values have become ingrained within individuals and ultimately shape their behaviour and values within various life domains. Such results also corroborate recent propositions by Hofstede and Hofstede (2005), who argue that while culture remains stable over time, rituals and practices (e.g. church attendance) are more susceptible to change. Furthermore, from the perspective of value hierarchies, this supports the theory that job satisfaction is not only a function of what an employee seeks to gain from their job, relative to what the employee perceives their job to be offering, but also the relative importance of the value (Locke, 1969). So even though 'confidence in church' has decreased between 1981 and 2008 (i.e. ranked at a relatively lower level on the hierarchy), as indicated in the preliminary analysis, it still has a positive influence on job satisfaction over the same time period. 
A similar finding is identified for 'always loving and respecting one's parents'; although the trend emphasised in the previous section showed that there has been an overall decrease, its positive influence on job satisfaction appears to be relatively stable across the four waves of the EVS. Fargher et al. (2008), who found a similar result for male respondents using data from wave 3 of EVS, attributed their finding to conformity values, which may spill over into a respondent's work domain.

Taken together, the results for the traditional vs secular-rational values are consistent with Hofstede's (1980) main thesis that culture is like one's mental software, a consistently reliable predictor as to how individuals within society are likely to think and act. In particular, our findings indicate that traditional values are a consistent predictor over time of individuals' perception of utility in their workplace. Inglehart and Baker (2000) also observed that while industrialisation brings with it a shift from traditional to secular-rational values, there is no ongoing effect evident post-industrialisation. That is, this dimension demonstrates relative stability beyond the initial surge in economic development. These findings provide support for hypothesis H2a.

For the second set of SCVs, those from survival vs self-expression, the results from the ordered logit regression generally counter the notion that culture remains stable across time. The first three variables under this domain (i.e. 'homosexuality is never justifiable', 'tolerance and respect are unimportant to teach at home' and 'would never sign a petition') displayed an overall decrease in their influence over job satisfaction across the four waves of EVS. This is in line with the results of the preliminary descriptive statistics (see Table 3), which showed a decrease in the mean values of 'homosexuality is never justifiable' and 'tolerance and respect are unimportant to teach at home'. Based on the results in Table 3 , the positive influence of 'homosexuality is never justifiable' on job satisfaction is only statistically significant in the first and third wave of the study, and this result represents 
changing and less rigid attitudes towards sexual orientation. The belief that 'tolerance and respect are unimportant to teach at home' had a statistically significant and positive impact on job satisfaction in the first wave of the study only. Furthermore, never expressing one's civil liberties through 'signing a petition' was positively related and statistically significant with respect to job satisfaction in the first three waves of the study. These results are not surprising in light of the empirical literature that shows that SCVs across various countries have generally moved towards self-expressive type values (Inglehart and Baker, 2000; Flanagan and Lee, 2003; Hagenaars et al., 2003) and with self-expression values on the rise throughout all countries for which longitudinal data is available (Welzel, 2010).

The second grouping of survival vs self-expression variables showed that values relating to 'have to be careful when trusting people' and 'child needs both parents to be happy' were only statistically significant determinants of job satisfaction in the second wave of the EVS. What is more, 'have to be careful when trusting people' is the only societal cultural variable that exhibits a relatively strong and negative impact on job satisfaction in 1990. This result aligns with the empirical findings by Fargher et al. (2008), who argued that interpersonal trust is a social construct, which ultimately shapes individuals' preferences and attitudes, including attitudes towards work.

In contrast to the group of variables characterising traditional values, the results from Table 3 and subsequent odds ratios presented in Table 4 show that there have been shifts in SCVs across the four waves of EVS, and especially with respect to values concerning survival vs self-expression. These shifts go against Hofstede's (1980) premise that culture is stable and a consistent and reliable predictor of how individuals will behave or act. The shifts have occurred on two distinct levels: (i) an overall shift towards a greater focus of selfexpression (i.e. displaying higher levels of tolerance for out-groups and respect for individuals' freedom of expression), and (ii) a continual reinvention of SCVs relating to 
interpersonal trust and two-parent families across two decades. The results also suggest that shifts towards SCVs more focused on self-expression do not influence workers' job satisfaction, at least not at conventionally accepted levels of statistical significance. This calls into question Inglehart and Baker's (2000) findings that individuals who are orientated towards self-expression values should display higher levels of subjective well-being. However, based on theoretical work by Locke (1969), if individuals do not perceive their job values as being achieved within the work environment (e.g. opportunities for self-expression) then low job satisfaction is likely to result. Therefore organisational programmes may need to be (re)aligned in support of changing cultures to ensure job satisfaction is being promoted and organisational benefits are being captured.

Overall, the results from Table 4 are relatively unambiguous and can be summarised succinctly by two main findings: (i) the time-invariant impact of traditional cultural values on job satisfaction, and (ii) the declining importance of survival values on job satisfaction. The latter of these lends support for hypothesis $\mathrm{H} 2 \mathrm{~b}$ and in particular highlights that the dynamic influence of self-expression values with respect to job satisfaction is in a negative direction over the sample period. Further research is required to delve deeper into the potential causes of these trends. For instance, are there country-specific factors that play a role in this sample from Europe, and/or are demographic shifts in the working-age population driving either of these outcomes? While this is beyond the scope of the paper, preliminary analysis of a proxy age cohort born in 1960 does reveal that the importance of 'confidence in church' is increasing in terms of its influence on job satisfaction, while the reverse is true for the value that 'homosexuality is never justifiable'.

Repeating the regression analysis for the age groups 21 to 30 in wave 1,31 to 40 in wave 2, 41 to 50 in wave 3 and 51 to 60 in wave 4 yields insignificant odds ratios for 'confidence in church' in 1981 and 1990, which increase to 1.118 and 1.250 (significant at 
the 5\% level) in 1999 and 2008, respectively. This evidence corroborates Smith (2012), who finds that belief in God is highest among older adults. When analysing differences among age groups, it is found that the largest uplift in belief in God occurred among those aged 58 and older, which is arguably in response to being at the age where there is an increasing anticipation of one's own mortality (Smith, 2012).

Using the same empirical approach reveals a contrasting pattern for 'homosexuality is never justifiable', with the odds ratios falling from 1.164 (significant at the 5\% level) in 1981 to 0.987 (insignificant) by 2008 . This indicates that at the start of an average individual's working life, having the value that 'homosexuality is never justifiable' actually increased job satisfaction levels, but by the end of their working life span (i.e. aged 51 to 60 in wave 4 ) this impact diminishes to a negligible effect. This result also supports the theory of value hierarchy (Locke, 1969), in that having the value of 'homosexuality is never justifiable' becomes relatively less important over an individual's working lifespan and, consequently, has a relatively lower impact on their job satisfaction towards the end. 


\section{Conclusions}

Determining the factors that influence workers' job satisfaction levels has become a growing point of interest for organisations due to its pervasive and multilayered impacts on success factors, e.g., productivity, competitiveness and prosperity. From a theoretical standpoint, at an individual level, SCVs shape what employees seek to achieve from their jobs and, through variation in the self-concept, affect the perception of satisfaction gained from the job. There is significant empirical support for this theoretical argument. Although the current body of empirical research is of undoubted value, it has predominately focused on examining the relationship between SCVs and job satisfaction at a single point in time (e.g. Georgellis and Lange, 2012; Konrad et al., 2013). On the other hand, there is a paucity of research examining this phenomenon over time. A significant gap in the current literature exists because (i) globalisation, greater movement of labour across national borders and a broader mix of intergenerational labour force are likely to combine and create greater dynamism in SCVs and (ii) the theoretical ambiguity surrounding the evolutionary nature of SCVs. With a focus on Europe, this study investigates the relationship between SCVs and job satisfaction over almost three decades, operationalises SCVS using traditional values that are ingrained in one's psyche and rituals/practices, which according to theory are more susceptible to change.

This paper makes use of the fourth wave of EVS and combines it with all previous waves collected since 1981. The ordered logit regression model was applied for a balanced group of countries over the four waves. At first, the model focused solely on sociodemographic characteristics as determinants of job satisfaction, where results were generally consistent with extant literature. One limitation of ensuring consistency in the method and variables across time was the exclusion of education from the investigation. Nonetheless, we would expect to capture educational attainment indirectly through the use of occupational status indicators. 
The empirical analyses were extended to include work-related characteristics, where the impact of PDM on job satisfaction stood out; having the freedom to be part of the decision-making process appears to be an important determinant of job satisfaction, and this result is stable to the inclusion of societal cultural characteristics. This is consistent with recent empirical research by Van der Westhuizen et al. (2012).

The key theoretical contributions of the paper are two-fold. First, we showed that SCVs are dynamic and have evolved over the period covered by the study. Second, despite these changes, the influence of traditional SCVs on job satisfaction has remained relatively constant despite the changes in the value ascribed to these variables. On the other hand, the influence of survival values on job satisfaction has declined. The empirical results partially support our propositions. They support the argument that there are two different types ofSCVs - those that are formed early in life and typically held unconsciously and those that are formed later in life such as visible cultural values (symbols, rituals), which are more transient - hence, it is important to distinguish and ascertain the impact of the different dimensions of SCVs on job satisfaction over time.

The results presented in this article are important for organisational management and policy formation, as asymmetries in SCVS may be critical to job satisfaction in the workplace. Job satisfaction moderates critical facets of firm performance such as retention rate, absenteeism rates, motivation, productivity and competitiveness. The generally accepted belief that SCVs are considerably stable in nature, and would therefore be a reliable predictor as to how individuals within the workplace are likely to think and act, must be called into question, specifically when cultures adopt values within the survival vs self-expression based perspective. Hence, it is not sufficient to focus on culture mix but to be cognisant of cultural shifts over time. This is important because job satisfaction is pervasive and it moderates 
critical facets of firm performance such as retention rates, absenteeism rates, motivation, productivity and competitiveness.

Due to the temporal gap between the most recent wave of EVS and the impending fifth wave in 2017, future research will be able to examine further the impact of cultural shifts in the last decade, as well as potentially investigate the impact on a sub-national basis. This study also suggests that age distribution within the workplace should be taken into consideration when developing and implementing organisational practices. Perhaps more open communication throughout the organisation can facilitate further understanding of the influence of societal culture on job satisfaction and how these evolve. Such understanding may assist in the development of effective strategies aimed at increasing job satisfaction, which in turn are likely to lead to improvements in productivity and competitiveness. 


\section{References}

Aggarwal, R., C. Kearney and B. Lucey (2009). 'Gravity as a cultural artefact: culture and distance in foreign portfolio investment', Conference papers of the FMA Annual Meeting.

Aycan, Z., R. N. Kanungo, M. Mendonca, K. et al. (2000). 'Impact of culture on human resource management practices: a 10-country comparison', Applied Psychology: An International Review, 49, pp. 192-221.

Ball-Rokeach, S. J. (1973). 'Values and violence: a test of subculture of violence thesis', American Sociological Review, 38, pp. 736-749.

Bellou, V. (2010). 'Organizational culture as a predictor of job satisfaction: the role of gender and age', Career Development International, 15, pp. 4-19.

Benassy-Quere, A., M. Coupet and T. Mayer (2005). 'Institutional determinants of foreign direct investment,' CEPI working paper \#2005-05.

Bernolak, I. (1997). 'Effective measurement and successful elements of company productivity: the basis of competitiveness and world prosperity', International Journal of Production Economics, 52, pp. 203-213.

Browaeys, M. and R. Price (2008). Understanding Cross-cultural Management. Essex, UK: Pearson Education.

Child, J. (1981). 'Culture, contingency and capitalism in the cross-national study of organisations'. In B. M. Staw and L. L. Cummings (eds), Research in Organizational Behavior, pp. 301-356. Greenwich, CT: JAI Press.

Chiva, R. and J. Alegre (2009). 'Organizational learning capability and job satisfaction: an empirical assessment in the ceramic tile industry', British Journal of Management, 20, pp. 323-340. 
Clark, A. E., A. Oswald, and P. Warr (1996). 'Is job satisfaction U-shaped in age?' Journal of Occupational and Organizational Psychology, 69, pp. 57-81.

Coyle-Shapiro, J. A.-M. and L. M. Shore (2007). 'The employee-organization relationship: where do we go from here?' Human Resource Management Review, 17, pp. 166-179.

Daft, R. L. (2007). Organisation Theory and Design, 9th edn. Mason, OH: Thomson, SouthWestern.

Dalton, R. J., P. M. Hac, P. T. Nghi and B. N. T. Ong (2002). 'Social relations and social capital in Vietnam: findings from the 2001 World Values Survey', Comparative Sociology, 1, pp. 369-386.

Deresky, H. (2011). International Management: Managing Across Borders and Cultures. Upper Saddle River, NJ: Pearson Education.

Draper, N. and H. Smith (1981). Applied Regression Analysis. New York: John Wiley \& Sons.

Draulans, V. and L. Halman (2005). 'Mapping contemporary Europe's moral and religious pluralist landscape: an analysis based on the most recent European Values Study', Journal of Contemporary Religion, 20, pp. 179-193.

DuBrin, A. J. (1991). 'Comparison of the job satisfaction and productivity of telecommuters versus in-house employees: a research note on work in progress', Psychological Reports, 68, pp 1223-1234.

European Values Study (EVS) (2014). Surveys: The four waves of the European Values Study. Retrieved from www.europeanvaluesstudy.eu [Accessed 11 June 2015]. 
Fargher, S., S. Kesting, T. Lange and G. Pacheco (2008). 'Cultural heritage and job satisfaction in Eastern and Western Europe', International Journal of Manpower, 29, pp. 630-650.

Fiske, S. T. and S. Taylor (1991). Social Cognition, 2nd ed. New York: McGraw-Hill.

Fitzsimmons, S. R. and C. Stamper (2014). 'How societal culture influences friction in the employee-organization relationship', Human Resource Management Review, 24, pp. 8094.

Flanagan, S. and A. R. Lee (2003). 'The new politics, culture wars, and the authoritarianlibertarian value change in advanced industrial democracies', Comparative Political Studies, 36, pp. 235-270.

Fletcher, C. and R. Williams (1996). 'Performance management, job satisfaction and organizational commitment', British Journal of Management, 7, pp. 169-179.

Furnham, A. and P. Springfield (1993). 'Personality and work performance: Myers-Briggs Type Indicator correlates of managerial performance in two cultures', Personality and Individual Differences, 14, pp. 145-153.

Gaspay, A., S. Dardan and L. Legorreta (2008). 'Software of the mind: a review of applications of Hofstede's theory to IT research', Journal of Information Technology Theory and Application, 9, pp. 1-37.

Georgellis, Y. and T. Lange (2012). 'Traditional versus secular values and the job-life satisfaction relationship across Europe', British Journal of Management, 23, pp. 437-454.

Ghemawat, P. and S. Reiche (2011). 'National cultural differences and multinational businesses', Globalization Note Series. IESE Business School. pp. 1-18. 
Hagenaars, J., L. Halman and G. Moors (2003). 'Exploring Europe’s basic values map'. In W. Arts, J. Hagenaars and L. Halman (eds), The Cultural Diversity of European Unity, pp. 23-58. Leiden, Netherlands: Brill.

Haller, M. (2002). 'Theory and method in the comparative study of values: critique and alternative to Inglehart', European Sociological Review, 18, pp. 139-158.

Halman, L. and V. Draulans (2004). Religious beliefs and practices in contemporary Europe. In W. Arts and L. Halman (eds), European Values at the Turn of the Millennium, pp. 283316. Leiden, Netherlands: Brill.

Halman, L. and V. Draulans (2006). 'How secular is Europe?' British Journal of Sociology, 57, pp. 179-193.

Helm, S. (2013). 'A matter of reputation and pride: associations between perceived external reputation, pride in membership, job satisfaction and turnover intentions', British Journal of Management, 24, pp. 542-556.

Hewling, A. (2005). 'Culture in the online class: using message analysis to look beyond nationality-based frames of reference', Journal of Computer-mediated Communication, 11, pp. 337-356.

Hitt, M. A., D. G. Sirmon, Y. Li, A. Ghobadian and J. A. Arregle (2012). ‘Institutional polycentricity, resource orchestration and firm performance: contingent influence of the environmental context on managing firm resources', Academy of Management, Annual Conference, Boston, MA, August.

Hofstede, G. (1980). Culture's Consequences: International Differences in Work-related Values. Beverly Hills, CA: Sage Publications. 
Hofstede, G. (1991). Cultures and Organizations: Software of the Mind. London: McGrawHill.

Hofstede, G. (2001). Culture's Consequences: Comparing Values, Behaviours, Institutions and Organizations across Nations, 2nd ed. Thousand Oaks, CA: Sage.

Hofstede, G. and G. J. Hofstede (2005). Cultures and Organizations: Software of the Mind, 2nd ed. New York: McGraw-Hill.

Hofstede, G., G. J. Hofstede and M. Minkov (2010). Cultures and Organizations: Software of the Mind, 3rd ed. New York: McGraw-Hill.

Hoppock, R. (1937). 'Job satisfaction of psychologists', Journal of Applied Psychology, 21, pp. 300-303.

Huang, X. and E. Van de Vliert (2004). 'Job level and national culture as joint roots of job satisfaction', Applied Psychology, 53, pp. 329-348.

Hui, C. H. (1990). 'Work attitudes, leadership styles, and managerial behaviors in different cultures'. In R. W. Brislin (ed.), Applied Cross-cultural Psychology, pp. 186-208. Thousand Oaks, CA: Sage Publications.

Hui, C. H., C. Yee and K. L. Eastman (1995). 'The relationship between individualismcollectivism and job satisfaction', Applied Psychology: An International Review, 44, pp. 276-282.

Husband, T. M. and A. Ghobadian (1981). 'Measuring total productivity in a batch production factory: a case study', International Journal of Production Research, 19, pp. $411-424$.

Inglehart, R. (2006). 'Mapping global values', Comparative Sociology, 5, pp. 115-136. 
Inglehart, R. and W. Baker (2000). 'Modernization, cultural change, and the persistence of traditional values', American Sociological Review, 65, pp. 19-55.

International Labour Organization (2010). International Standard Classification of Occupations. Available at www.ilo.org/public/english/bureau/stat/isco/isco08/index.htm. [Accessed 11 June 2015].

Jones, M. and I. Alony (2007). 'The cultural impact of information systems - through the eyes of Hofstede - a critical journey', Issues in Informing Science and Information Technology, 4, pp. 407-419.

Judge, T. A. and J. E. Bono (2001). 'Relationship of core self-evaluations traits - self-esteem, generalized self-efficacy, locus of control, and emotional stability - with job satisfaction and job performance: a meta-analysis', Journal of Applied Psychology, 86, pp. 80-92.

Kerr, W. (1948). 'On the validity and reliability of the job satisfaction tear ballot', Journal of Applied Psychology, 32, pp. 275-281.

Kirkman, B. L. and D. L. Shapiro (1997). 'The impact of cultural values on employee resistance to teams: toward a model of globalized self-managing work team effectiveness', Academy of Management Review, 22, pp. 730-757.

Kirkman, B. L. and D. L. Shapiro (2001). 'The impact of cultural values on job satisfaction and organizational commitment in self-managing work teams: the mediating role of employee resistance', Academy of Management Journal, 44, pp. 557-569.

Knutsen, O. (2009). 'Regions, social structure and value orientations: a comparative study of 15 West European countries,' European Political Science Review, 1, pp. 401-434. 
Konrad, A. M., M. E. Moore, E. S. W. Ng, A. J. Doherty and K. Breward (2013). 'Temporary work, underemployment and workplace accommodations: relationship to well-being for workers with disabilities,' British Journal of Management, 24, pp. 367-382.

Kotter, J. P. and L. A. Schlesinger (1979). 'Choosing strategies for change', Harvard Business Review, 57, pp. 106-114.

Kovach, K. A. (1995). 'Employee motivation: addressing a crucial factor in your organization's performance', Employment Relations Today, 22, pp. 93-107.

Lange, T. (2009). 'Attitudes, attributes and institutions: determining job satisfaction in Central and Eastern Europe', Employee Relations, 31, pp. 81-97.

Lawrence, B. L., C. Hardy and N. Phillips (2002). 'Institutional effects of interorganizational collaboration: the emergence of proto-institutions', Academy of Management Journal, 41, pp. 281-290.

Lee, F. C. and J. Tang (2000). 'Productivity levels and international competitiveness between Canadian and U.S. industries,' American Economic Review, 90, pp 176-179.

Locke, E. A. (1969). 'What is job satisfaction?', Organizational Behavior and Human Performance, 4, pp. 309-336.

Lund, D. B. (2003). 'Organizational culture and job satisfaction', Journal of Business and Industrial Marketing, 18, pp. 219-236.

Luthans, F. (1993). 'A paradigm shift in Eastern Europe: some helpful management development techniques', Journal of Management Development, 12, pp. 53-60.

Magnusson, P., R. Peterson and S. A. Westjohn (2014). 'The influence of national cultural values on the use of reward alignment to improve sales collaboration', International Marketing Review, 31, pp. 30-50. 
Maslow, A. H. (1970). Motivation and Personality. New York: Harper \& Row.

Mason, E. (1997). 'A case study of gender differences in job satisfaction subsequent to implementation of an employment equity programme', British Journal of Management, $\mathbf{8}$, pp. 163-173.

Miller, K. I. and P. R. Monge (1986). 'Participation, satisfaction, and productivity: a metanalytic review, Academy of Management Journal, 29, pp. 727-753.

Miller, J. G., D. M. Bersoff and R. I. Harwood (1990). 'Perceptions of social responsibilities in India and the United States: moral imperatives or personal decisions', Journal of Personality and Social Psychology, 58, pp. 33-47.

Moutafi, J., A. Furnham and J. Crump (2007). 'Is managerial level related to personality?' British Journal of Management, 18, pp. 272-280.

Muellbauer, J. (1986). 'The assessment: productivity and competitiveness in British manufacturing', Oxford Review of Economic Policy, 2, pp. i-xxv.

Muellbauer, J. (1991). 'Productivity and competitiveness', Oxford Review of Economic Policy, 7, pp. 99-117.

Muller, V., N. Rosenbusch and A. Bausch (2013). 'Success patterns of exploratory and exploitative innovation: a meta-analysis of the institutional factors', Journal of Management, 39, pp. 1606-1636.

Myers, M. D. and F. B. Tan (2002). 'Beyond models of national culture in information systems research', Journal of Global Information Management, 10, pp. 1-19.

North, D. C. (1990). Institutions, Institutional Change and Economic Performance. Cambridge: Cambridge University Press. 
Oosterbeek, H., R. Sloof and G. van de Kuilen (2004). 'Cultural differences in ultimatum game experiments: evidence from a meta-analysis', Experimental Economics, 7, pp. 171188.

Oyserman, D. (2001). 'Self-concept and identity'. In A. Tesser and N. Schwarz (eds), The Blackwell Handbook of Social Psychology, pp. 499-517. Malden, MA: Blackwell.

Oyserman, D., H. M. Coon and M. Kemmelmeier (2002). 'Rethinking individualism and collectivism: evaluation of theoretical assumptions and meta-analyses', Psychological Bulletin, 128, pp. 3-72.

Peretz, H., and Y. Fried (2012). 'National Cultures, Performance Appraisal Practices, and Organizational Absenteeism and Turnover: A Study across 21 Countries', Journal of Applied Psychology, 97, 448-459.

Probst, T. M. and J. Lawler (2006). 'Cultural values as moderators of employee reactions to job insecurity: the role of individualism and collectivism', Applied Psychology, 55, pp. 234-254.

Rahim, A. (1981). 'Job satisfaction as a function of personality-job congruence: a study with Jungian psychological types', Psychological Reports, 49, pp. 496-498.

Riggle, R. J., D. R. Edmondson and J. D. Hansen (2009). 'A meta-analysis of the relationship between perceived organizational support and job outcomes: 20 years of research', Journal of Business Research, 62, pp. 1027-1030.

Ritz, A. and G. A. Brewer (2013). 'Does societal culture affect public service motivation? Evidence of sub-national differences in Switzerland', International Public Management Journal, 16, pp. 224-251. 
Saari, L. M. and T. A. Judge (2004). 'Employee attitudes and job satisfaction', Human Resource Management, 43, pp. 395-407.

Sagie, A. and Z. Aycan (2003). 'A cross-cultural analysis of participative decision-making in organizations', Human Relations, 5, pp. 453-473.

Saridakis, G., Muñoz Torres, R. and S. Johnstone (2013). 'Do human resource practices enhance organizational commitment in SMEs with low employee satisfaction?' British Journal of Management, 24, pp. 445-458.

Scott, S. G. and V. R. Lane (2000). 'A stakeholder approach to organisational identity', Academy of Management Review, 25, pp. 43-62.

Sengupta, S. S. and J. B. P. Sinha (2005). 'Perceived dimensions of societal and organisational culture and their impact on managerial work behaviour', Journal of Management Research, 5, pp. 143-172.

Smith, T. (2012). Beliefs About God Across Time and Countries. Report for International Social Survey Program and General Social Survey.

Smith, P. B., S. Dugan and F. Trompenaars (1996). 'National culture and the values of organisational employees: a dimensional analysis across 43 nations', Journal of CrossCultural Psychology, 21, pp. 231-264.

Taylor, S., O. Levy, N. A. Boyacigiller and S. Beechler (2008). 'Employee commitment in MNCs: impacts of organizational culture, HRM, and top management orientations', International Journal of Human Resource Management, 19, pp. 501-527.

Thomas, D. C., S. R. Fitzsimmons, E. C. Ravlin et al. (2010). 'Psychological contracts across cultures', Organization Studies, 31, pp. 1437-1458. 
Van der Westhuizen, D. W., G. Pacheco and D. J. Webber (2012). 'Culture, participative decision making and job satisfaction', International Journal of Human Resource Management, 23, pp. 2661-2679.

Voicu, M. (2009). 'Religion and gender across Europe', Social Compass, 56, pp. 144-162.

Wanous, J. P., A. E. Reichers and M. J. Hudy (1997). 'Overall job satisfaction: how good are single-item measures?' Journal of Applied Psychology, 82, pp. 247-252.

Wasti, S. (1998). 'Cultural barriers in the transferability of Japanese and American human resource practices to developing countries: the Turkish case', International Journal of Human Resource Management, 9, pp. 608-631.

Welzel, C. (2010). 'How selfish are self-expression values? A civicness test', Journal of Cross-cultural Psychology, 41, pp. 152-174.

Wong, W-K. (2007) 'Comparing the fit of gravity models for difference cross-border flows', Working paper. Department of Economics, National University of Singapore.

Yamamura, J. H., M. Satoh and Y. Stedham (2003). Changing dimensions of national culture in Japan: applying the Hofstede framework. Economic Research Center Discussion Paper No. 143. 
Figure 1. Changes in cultural values over time

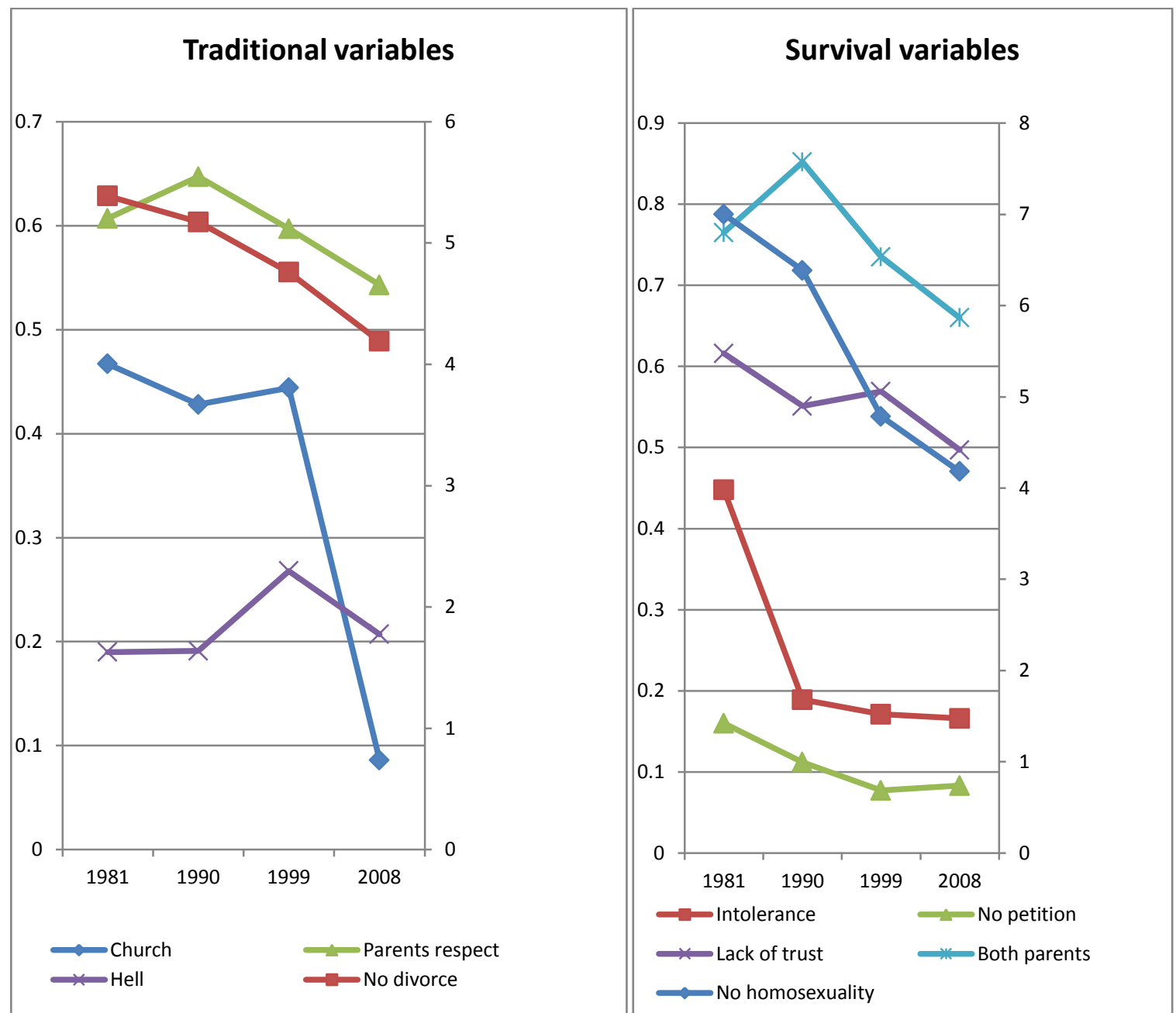

Note: Source of data - First four waves of the EVS. Authors' compilation. 
Table 1. Participating countries: percentage of respondents and job satisfaction ratings

\begin{tabular}{lcc}
\hline Country & $\begin{array}{c}\text { Percentage of sample } \\
(\mathbf{2 0 0 8} \text {, Model I) }\end{array}$ & $\begin{array}{c}\text { Job satisfaction } \\
\text { (rating) }\end{array}$ \\
\hline Belgium & 10.7 & 7.75 \\
Denmark & 10.2 & 7.96 \\
France & 10.8 & 7.26 \\
Germany & 12.7 & 7.55 \\
Great Britain & 7.2 & 7.32 \\
Iceland & 6.7 & 8.31 \\
Ireland & 4.3 & 8.10 \\
Italy & 5.9 & 7.33 \\
Malta & 4.2 & 7.59 \\
The Netherlands & 9.7 & 7.66 \\
Northern Ireland & 2.0 & 7.62 \\
Spain & 4.5 & 7.26 \\
Sweden & 9.2 & 7.59 \\
\hline
\end{tabular}


Culture and Job Satisfaction

Table 2. Descriptive statistics

\begin{tabular}{|c|c|c|c|c|c|}
\hline & \multirow[t]{2}{*}{ Definition } & \multicolumn{4}{|c|}{ Mean (standard deviation) } \\
\hline & & 1981 & 1990 & 1999 & 2008 \\
\hline \multicolumn{6}{|c|}{ Socio-demographic characteristics } \\
\hline Job satisfaction & $\begin{array}{l}\text { Ordinal categorical variable on a scale } 1 \text { to } 10(1=\text { extremely dissatisfied, } 10=\text { extremely } \\
\text { satisfied }) \text { minus average country job satisfaction }\end{array}$ & $\begin{array}{l}-0.165 \\
(2.050)\end{array}$ & $\begin{array}{l}0.013 \\
(1.942)\end{array}$ & $\begin{array}{l}-0.085 \\
(1.829)\end{array}$ & $\begin{array}{l}0.017 \\
(1.791)\end{array}$ \\
\hline Male & Dummy variable: 1 for male; 0 otherwise & $\begin{array}{l}0.602 \\
(0.490)\end{array}$ & $\begin{array}{l}0.589 \\
(0.492)\end{array}$ & $\begin{array}{l}0.551 \\
(0.497)\end{array}$ & $\begin{array}{l}0.505 \\
(0.500)\end{array}$ \\
\hline Age & Age in years & $\begin{array}{l}35.109 \\
(12.349)\end{array}$ & $\begin{array}{l}37.988 \\
(11.600)\end{array}$ & $\begin{array}{l}38.982 \\
(10.763)\end{array}$ & $\begin{array}{l}41.545 \\
(11.235)\end{array}$ \\
\hline Married & Dummy variable: 1 for married or registered partnership; 0 otherwise & $\begin{array}{l}0.682 \\
(0.466)\end{array}$ & $\begin{array}{l}0.707 \\
(0.455)\end{array}$ & $\begin{array}{l}0.600 \\
(0.490)\end{array}$ & $\begin{array}{l}0.583 \\
(0.493)\end{array}$ \\
\hline Widowed & Dummy variable: 1 for widowed; 0 otherwise & $\begin{array}{l}0.017 \\
(0.128)\end{array}$ & $\begin{array}{l}0.018 \\
(0.133)\end{array}$ & $\begin{array}{l}0.013 \\
(0.112)\end{array}$ & $\begin{array}{l}0.015 \\
(0.121)\end{array}$ \\
\hline Med income & Dummy variable: 1 for middle income; 0 otherwise & $\begin{array}{l}0.526 \\
(0.499)\end{array}$ & $\begin{array}{l}0.468 \\
(0.499)\end{array}$ & $\begin{array}{l}0.553 \\
(0.497)\end{array}$ & $\begin{array}{l}0.546 \\
(0.498)\end{array}$ \\
\hline High income & Dummy variable: 1 for high income; 0 otherwise & $\begin{array}{l}0.407 \\
(0.491)\end{array}$ & $\begin{array}{l}0.307 \\
(0.461)\end{array}$ & $\begin{array}{l}0.282 \\
(0.450)\end{array}$ & $\begin{array}{l}0.395 \\
(0.489)\end{array}$ \\
\hline Part time & Dummy variable: 1 for employed part time; 0 otherwise & $\begin{array}{l}0.145 \\
(0.353)\end{array}$ & $\begin{array}{l}0.122 \\
(0.327)\end{array}$ & $\begin{array}{l}0.174 \\
(0.379)\end{array}$ & $\begin{array}{l}0.166 \\
(0.372)\end{array}$ \\
\hline Skilled & Dummy variable: 1 for skilled; 0 otherwise & $\begin{array}{l}0.384 \\
(0.487)\end{array}$ & $\begin{array}{l}0.379 \\
(0.485)\end{array}$ & $\begin{array}{l}0.404 \\
(0.491)\end{array}$ & $\begin{array}{l}0.331 \\
(0.471)\end{array}$ \\
\hline Less skilled & Dummy variable: 1 for less skilled; 0 otherwise & $\begin{array}{l}0.327 \\
(0.469)\end{array}$ & $\begin{array}{l}0.331 \\
(0.471)\end{array}$ & $\begin{array}{l}0.289 \\
(0.453)\end{array}$ & $\begin{array}{l}0.245 \\
(0.430)\end{array}$ \\
\hline Manual & Dummy variable : 1 for manual; 0 otherwise & $\begin{array}{l}0.185 \\
(0.388)\end{array}$ & $\begin{array}{l}0.124 \\
(0.329)\end{array}$ & $\begin{array}{l}0.101 \\
(0.302)\end{array}$ & $\begin{array}{l}0.133 \\
(0.340)\end{array}$ \\
\hline \multicolumn{6}{|c|}{ Work-related characteristics } \\
\hline PDM & $\begin{array}{l}\text { Participatory decision-making. Ordinal categorical variable on a scale } 1 \text { to } 10(1=\text { no decision- } \\
\text { making freedom in job, } 10=\text { great deal of decision-making freedom in job })\end{array}$ & $\begin{array}{l}6.270 \\
(2.627)\end{array}$ & $\begin{array}{l}6.636 \\
(2.481)\end{array}$ & $\begin{array}{l}6.795 \\
(2.397)\end{array}$ & $\begin{array}{l}6.900 \\
(2.264)\end{array}$ \\
\hline Good pay & $\begin{array}{l}\text { Dummy variable: } 1 \text { if individual thinks good pay is an important job characteristic; } 0 \\
\text { otherwise }\end{array}$ & $\begin{array}{l}0.686 \\
(0.464)\end{array}$ & $\begin{array}{l}0.732 \\
(0.443)\end{array}$ & $\begin{array}{l}0.794 \\
(0.405)\end{array}$ & $\begin{array}{l}0.717 \\
(0.451)\end{array}$ \\
\hline Pleasant people & $\begin{array}{l}\text { Dummy variable: } 1 \text { if individual thinks sense of belonging/pleasant co-workers is an important } \\
\text { job characteristic; } 0 \text { otherwise }\end{array}$ & $\begin{array}{l}0.735 \\
(0.442)\end{array}$ & $\begin{array}{l}0.738 \\
(0.440)\end{array}$ & $\begin{array}{l}0.787 \\
(0.409)\end{array}$ & $\begin{array}{l}0.764 \\
(0.425)\end{array}$ \\
\hline Job security & $\begin{array}{l}\text { Dummy variable: } 1 \text { if individual thinks job security is an important job characteristic; } 0 \\
\text { otherwise }\end{array}$ & $\begin{array}{l}0.579 \\
(0.494)\end{array}$ & $\begin{array}{l}0.601 \\
(0.490)\end{array}$ & $\begin{array}{l}0.581 \\
(0.493)\end{array}$ & $\begin{array}{l}0.514 \\
(0.500)\end{array}$ \\
\hline Good hours & $\begin{array}{l}\text { Dummy variable: } 1 \text { if individual thinks good working hours is an important job characteristic; } \\
0 \text { otherwise }\end{array}$ & $\begin{array}{l}0.465 \\
(0.499)\end{array}$ & $\begin{array}{l}0.457 \\
(0.498)\end{array}$ & $\begin{array}{l}0.526 \\
(0.499)\end{array}$ & $\begin{array}{l}0.427 \\
(0.495)\end{array}$ \\
\hline Use initiative & $\begin{array}{l}\text { Dummy variable: } 1 \text { if individual thinks opportunity to use initiative (freedom for self- } \\
\text { expression) is an important job characteristic; } 0 \text { otherwise }\end{array}$ & $\begin{array}{l}0.472 \\
(0.499)\end{array}$ & $\begin{array}{l}0.553 \\
(0.497)\end{array}$ & $\begin{array}{l}0.564 \\
(0.496)\end{array}$ & $\begin{array}{l}0.504 \\
(0.500)\end{array}$ \\
\hline Achieve something & $\begin{array}{l}\text { Dummy variable: } 1 \text { if individual thinks potential to achieve something (ego motivation) is an } \\
\text { important job characteristic; } 0 \text { otherwise }\end{array}$ & $\begin{array}{l}0.523 \\
(0.500)\end{array}$ & $\begin{array}{l}0.601 \\
(0.490)\end{array}$ & $\begin{array}{l}0.614 \\
(0.487)\end{array}$ & $\begin{array}{l}0.537 \\
(0.499)\end{array}$ \\
\hline
\end{tabular}


Dummy variable: 1 if individual thinks task knowledge (job that meets one's abilities) is an

$(0.473)$

\section{Traditional vs secular-rationa}

Confidence in church

Dummy variable: 1 if great deal or quite a lot of confidence in church; 0 otherwise

0.467

Divorce is never justifiable

Ordinal categorical variable on a scale 1 to 10

( 1 = divorce is always justifiable; $10=$ divorce is never justifiable $)$

Always love and respect

Dummy variable: 1 if always love and respect parents; 0 otherwise

0.444

one's parents

Dummy variable: 1 if believes in hell; 0 otherwise

5.388
$(2.932)$

$(0.495)$

0.444

0.086

0.607

5.174

$(0.497)$

$(0.280)$

Believes in hell

Dumny variable: 1 if believes in hell; 0 otherwise

$(0.488)$

$(2.716)$
0.647

4.760
$(2.841)$

\section{Survival vs self-expression}

Homosexuality is never

justifiable

Ordinal categorical variable on a scale 1 to $10(1=$ homosexuality is always justifiable; $10=$

0.190

$(0.478)$

0.597

4.188

$(0.392)$

0.191

(0.491)

0.543

Tolerance and respect are

unimportant to teach at home

homosexuality is never justifiable)

$(0.393)$

0.268

$(0.498)$

Dummy variable: 1 if individual didn't mention teaching tolerance and respect at home as

$7.001 \quad 6.386$

$(0.443)$

$(0.406$

Would never s

Dertant: 0 otherwise

0.448

$6.386 \quad 4.786$

Dummy variable: 1 if would never sign a petition; 0 otherwise

$\begin{array}{ll}0.448 & 0.189 \\ (0.497) & (0.392)\end{array}$

(3.328)

4.182

Have to be careful when

trusting people

Dummy variable: 1 if have to be careful when trusting people; 0 otherwise

0.160

0.112

0.171

$(3.143)$

$(0.367)$

$(0.376)$

$(0.372)$

Child needs both parents to be

Dummy variable: 1 if child needs both parents to grow up happy; 0 otherwise

$(0.267)$

0.083
$(0.275)$

0.765

(0.497)

0.569

0.497

$\begin{array}{llll}0.765 & 0.852 & 0.735 & 0.660\end{array}$

happy

Sample size

3,128

(0.355)

Note: standard deviations in parentheses.

Reference categories for socio-demographic characteristics are Female, Non-married or widowed, Low income, Full time, Professional.

(0.442)

4,868 


\section{Culture and Job Satisfaction}

Table 3. Job satisfaction model

\begin{tabular}{|c|c|c|c|c|c|c|c|c|c|c|c|c|}
\hline \multirow{3}{*}{$\begin{array}{l}\text { Variable } \\
\text { Socio-demographic } \\
\text { characteristics } \\
\text { Male }\end{array}$} & \multirow{2}{*}{$\begin{array}{l}1981 \\
\text { Model I }\end{array}$} & \multirow[b]{2}{*}{ Model II } & \multirow[b]{2}{*}{ Model III } & \multicolumn{3}{|l|}{1990} & \multicolumn{3}{|l|}{1999} & \multicolumn{3}{|l|}{2008} \\
\hline & & & & Model I & Model II & Model III & Model I & Model II & Model III & Model I & Model II & Model III \\
\hline & $\begin{array}{l}-0.018 \\
(0.068)\end{array}$ & $\begin{array}{l}-0.128 \\
(0.079)\end{array}$ & $\begin{array}{l}-0.098 \\
(0.096)\end{array}$ & $\begin{array}{l}0.040^{*} \\
(0.030)\end{array}$ & $\begin{array}{l}-0.071 * \\
(0.043)\end{array}$ & $\begin{array}{l}-0.077 \\
(0.075)\end{array}$ & $\begin{array}{l}0.109 * * \\
(0.056)\end{array}$ & $\begin{array}{l}-0.033 \\
(0.064)\end{array}$ & $\begin{array}{l}-0.063 \\
(0.072)\end{array}$ & $\begin{array}{l}-0.047 \\
(0.061)\end{array}$ & $\begin{array}{l}-0.152 * * \\
(0.061)\end{array}$ & $\begin{array}{l}-0.170 * * * \\
(0.056)\end{array}$ \\
\hline Age & $\begin{array}{l}0.035^{* * * *} \\
(0.013)\end{array}$ & $\begin{array}{l}-0.001 \\
(0.012)\end{array}$ & $\begin{array}{l}0.008 \\
(0.014)\end{array}$ & $\begin{array}{l}-0.011 \\
(0.012)\end{array}$ & $\begin{array}{l}-0.034 * * * \\
(0.013)\end{array}$ & $\begin{array}{l}-0.017 \\
(0.012)\end{array}$ & $\begin{array}{l}-0.050 * * \\
(0.024)\end{array}$ & $\begin{array}{l}-0.086^{* * * *} \\
(0.026)\end{array}$ & $\begin{array}{l}-0.086^{* * * *} \\
(0.027)\end{array}$ & $\begin{array}{l}-0.040 * * * \\
(0.014)\end{array}$ & $\begin{array}{l}-0.052 * * * \\
(0.010)\end{array}$ & $\begin{array}{l}-0.049 * * * \\
(0.012)\end{array}$ \\
\hline $\mathrm{Age}^{2}$ & $\begin{array}{l}-0.0002 \\
(0.0002)\end{array}$ & $\begin{array}{l}0.0002 \\
(0.0001)\end{array}$ & $\begin{array}{l}0.0000 \\
(0.0002)\end{array}$ & $\begin{array}{l}0.0003 * * \\
(0.0001)\end{array}$ & $\begin{array}{l}0.001 * * * \\
(0.0002)\end{array}$ & $\begin{array}{l}0.0003 * * \\
(0.002)\end{array}$ & $\begin{array}{l}0.0008^{* * * *} \\
(0.0003)\end{array}$ & $\begin{array}{l}0.001 * * * \\
(0.0003)\end{array}$ & $\begin{array}{l}0.001 * * * \\
(0.0003)\end{array}$ & $\begin{array}{l}0.001 * * * \\
(0.0002)\end{array}$ & $\begin{array}{l}0.001 * * * \\
(0.0001)\end{array}$ & $\begin{array}{l}0.001 * * * \\
(0.0002)\end{array}$ \\
\hline Married & $\begin{array}{l}0.124 \\
(0.079)\end{array}$ & $\begin{array}{l}0.114 \\
(0.083)\end{array}$ & $\begin{array}{l}0.115 \\
(0.125)\end{array}$ & $\begin{array}{l}0.130^{*} \\
(0.079)\end{array}$ & $\begin{array}{l}0.097 \\
(0.073)\end{array}$ & $\begin{array}{l}0.056 \\
(0.106)\end{array}$ & $\begin{array}{l}0.160 * * * \\
(0.055)\end{array}$ & $\begin{array}{l}0.208^{* * * *} \\
(0.062)\end{array}$ & $\begin{array}{l}0.159^{* *} \\
(0.066)\end{array}$ & $\begin{array}{l}0.157^{* * *} \\
(0.071)\end{array}$ & $\begin{array}{l}0.099^{*} \\
(0.060)\end{array}$ & $\begin{array}{l}0.076 \\
(0.060)\end{array}$ \\
\hline Widowed & $\begin{array}{l}0.373 * \\
(0.231)\end{array}$ & $\begin{array}{l}0.369 * * \\
(0.167)\end{array}$ & $\begin{array}{l}0.247 \\
(0.273)\end{array}$ & $\begin{array}{l}0.028 \\
(0.184)\end{array}$ & $\begin{array}{l}0.048 \\
(0.225)\end{array}$ & $\begin{array}{l}-0.009 \\
(0.259)\end{array}$ & $\begin{array}{l}0.222 \\
(0.237)\end{array}$ & $\begin{array}{l}0.114 \\
(0.191)\end{array}$ & $\begin{array}{l}0.154 \\
(0.272)\end{array}$ & $\begin{array}{l}0.069 \\
(0.234)\end{array}$ & $\begin{array}{l}0.163 \\
(0.193)\end{array}$ & $\begin{array}{l}0.147 \\
(0.183)\end{array}$ \\
\hline Med income & $\begin{array}{l}0.206 \\
(0.102)\end{array}$ & $\begin{array}{l}0.098 \\
(0.119)\end{array}$ & $\begin{array}{l}0.126 \\
(0.182)\end{array}$ & $\begin{array}{l}0.135^{* * *} \\
(0.052)\end{array}$ & $\begin{array}{l}0.090 \\
(0.092)\end{array}$ & $\begin{array}{l}0.030 \\
(0.123)\end{array}$ & $\begin{array}{l}0.126 \\
(0.124)\end{array}$ & $\begin{array}{l}-0.055 \\
(0.140)\end{array}$ & $\begin{array}{l}-0.058 \\
(0.158)\end{array}$ & $\begin{array}{l}0.175 \\
(0.129)\end{array}$ & $\begin{array}{l}-0.098 \\
(0.157)\end{array}$ & $\begin{array}{l}-0.115 \\
(0.143)\end{array}$ \\
\hline High income & $\begin{array}{l}0.333 \\
(0.206) \\
\end{array}$ & $\begin{array}{l}0.088 \\
(0.205) \\
\end{array}$ & $\begin{array}{l}0.122 \\
(0.265) \\
\end{array}$ & $\begin{array}{l}0.234 * * \\
(0.095) \\
\end{array}$ & $\begin{array}{l}-0.077 \\
(0.102)\end{array}$ & $\begin{array}{l}-0.153 \\
(0.154) \\
\end{array}$ & $\begin{array}{l}0.238 \\
(0.156) \\
\end{array}$ & $\begin{array}{l}-0.125 \\
(0.167) \\
\end{array}$ & $\begin{array}{l}-0.058 \\
(0.172)\end{array}$ & $\begin{array}{l}0.375 \\
(0.231)\end{array}$ & $\begin{array}{l}-0.134 \\
(0.223) \\
\end{array}$ & $\begin{array}{l}-0.121 \\
(0.203) \\
\end{array}$ \\
\hline \multicolumn{13}{|c|}{ Work-related characteristics } \\
\hline Part time & & $\begin{array}{l}-0.031 \\
(0.104)\end{array}$ & $\begin{array}{l}0.023 \\
(0.099)\end{array}$ & & $\begin{array}{l}-0.040 \\
(0.124)\end{array}$ & $\begin{array}{l}0.043 \\
(0.096)\end{array}$ & & $\begin{array}{l}-0.138 \\
(0.091)\end{array}$ & $\begin{array}{l}-0.156^{*} \\
(0.069)\end{array}$ & & $\begin{array}{l}0.056 \\
(0.130)\end{array}$ & $\begin{array}{l}0.070 \\
(0.127)\end{array}$ \\
\hline Skilled & & $\begin{array}{l}0.835 \\
(0.143)\end{array}$ & $\begin{array}{l}0.099 \\
(0.127)\end{array}$ & & $\begin{array}{l}-0.005 \\
(0.110)\end{array}$ & $\begin{array}{l}-0.039 \\
(0.093)\end{array}$ & & $\begin{array}{l}-0.033 \\
(0.088)\end{array}$ & $\begin{array}{l}-0.019 \\
(0.073)\end{array}$ & & $\begin{array}{l}-0.078 \\
(0.086)\end{array}$ & $\begin{array}{l}-0.114 \\
(0.070)\end{array}$ \\
\hline Less skilled & & $\begin{array}{l}0.178 \\
(0.149)\end{array}$ & $\begin{array}{l}0.051 \\
(0.124)\end{array}$ & & $\begin{array}{l}0.129 \\
(0.115)\end{array}$ & $\begin{array}{l}0.097 \\
(0.112)\end{array}$ & & $\begin{array}{l}-0.031 \\
(0.069)\end{array}$ & $\begin{array}{l}-0.029 \\
(0.085)\end{array}$ & & $\begin{array}{l}0.028 \\
(0.081)\end{array}$ & $\begin{array}{l}0.027 \\
(0.093)\end{array}$ \\
\hline Manual & & $\begin{array}{l}-0.147 \\
(0.156)\end{array}$ & $\begin{array}{l}-0.293^{*} \\
(0.150)\end{array}$ & & $\begin{array}{l}-0.050 \\
(0.159)\end{array}$ & $\begin{array}{c}-0.132 \\
(0.159)\end{array}$ & & $\begin{array}{l}0.015 \\
(0.191)\end{array}$ & $\begin{array}{l}-0.068 \\
(0.189)\end{array}$ & & $\begin{array}{l}0.004 \\
(0.124)\end{array}$ & $\begin{array}{l}0.025 \\
(0.142)\end{array}$ \\
\hline PDM & & $\begin{array}{l}0.350^{* * * *} \\
(0.028)\end{array}$ & $\begin{array}{l}0.340 * * * \\
(0.026)\end{array}$ & & $\begin{array}{l}0.361 * * * \\
(0.023)\end{array}$ & $\begin{array}{l}0.359^{* * * *} \\
(0.012)\end{array}$ & & $\begin{array}{l}0.345^{* * * *} \\
(0.020)\end{array}$ & $\begin{array}{l}0.338^{* * * *} \\
(0.020)\end{array}$ & & $\begin{array}{l}0.412 * * * \\
(0.021)\end{array}$ & $\begin{array}{l}0.412 * * * \\
(0.017)\end{array}$ \\
\hline Good pay & & $\begin{array}{l}-0.285^{* * * *} \\
(0.067)\end{array}$ & $\begin{array}{l}-0.245^{* * * *} \\
(0.056)\end{array}$ & & $\begin{array}{l}-0.105^{*} \\
(0.059)\end{array}$ & $\begin{array}{c}-0.109 \\
(0.063)\end{array}$ & & $\begin{array}{l}-0.124 * * \\
(0.061)\end{array}$ & $\begin{array}{l}-0.165 * * * \\
(0.065)\end{array}$ & & $\begin{array}{c}-0.039 \\
(0.061)\end{array}$ & $\begin{array}{c}-0.074 \\
(0.058)\end{array}$ \\
\hline Pleasant people & & $\begin{array}{l}0.087 \\
(0.107)\end{array}$ & $\begin{array}{l}0.095 \\
(0.125)\end{array}$ & & $\begin{array}{l}0.075 \\
(0.059)\end{array}$ & $\begin{array}{l}0.135^{*} \\
(0.078)\end{array}$ & & $\begin{array}{l}-0.062 \\
(0.083)\end{array}$ & $\begin{array}{l}0.074 \\
(0.069)\end{array}$ & & $\begin{array}{l}0.155 \\
(0.090)\end{array}$ & $\begin{array}{l}0.202^{* *} \\
(0.085)\end{array}$ \\
\hline Job security & & $\begin{array}{l}0.243 * * * \\
(0.082)\end{array}$ & $\begin{array}{l}0.273^{* * * *} \\
(0.068)\end{array}$ & & $\begin{array}{l}0.181 * * * \\
(0.066)\end{array}$ & $\begin{array}{l}0.114 \\
(0.095)\end{array}$ & & $\begin{array}{l}0.215^{*} \\
(0.124)\end{array}$ & $\begin{array}{l}0.136 \\
(0.127)\end{array}$ & & $\begin{array}{l}0.137 \\
(0.148)\end{array}$ & $\begin{array}{l}0.159 \\
(0.152)\end{array}$ \\
\hline Good hours & & $\begin{array}{l}-0.006 \\
(0.060)\end{array}$ & $\begin{array}{l}-0.033 \\
(0.061)\end{array}$ & & $\begin{array}{l}-0.156^{* * * *} \\
(0.050)\end{array}$ & $\begin{array}{l}-0.114 * * \\
(0.057)\end{array}$ & & $\begin{array}{l}-0.043 \\
(0.060)\end{array}$ & $\begin{array}{l}-0.035 \\
(0.050)\end{array}$ & & $\begin{array}{l}-0.165 * * \\
(0.082)\end{array}$ & $\begin{array}{l}-0.193^{* *} \\
(0.076)\end{array}$ \\
\hline Use initiative & & $\begin{array}{l}0.004 \\
(0.076)\end{array}$ & $\begin{array}{l}0.090 \\
(0.056)\end{array}$ & & $\begin{array}{l}-0.021 \\
(0.046)\end{array}$ & $\begin{array}{l}0.027 \\
(0.057)\end{array}$ & & $\begin{array}{l}-0.048 \\
(0.070)\end{array}$ & $\begin{array}{l}0.010 \\
(0.081)\end{array}$ & & $\begin{array}{l}-0.209 * * * \\
(0.078)\end{array}$ & $\begin{array}{l}-0.125^{* *} \\
(0.060)\end{array}$ \\
\hline Achieve something & & $\begin{array}{l}0.072 \\
(0.067)\end{array}$ & $\begin{array}{l}0.045 \\
(0.081)\end{array}$ & & $\begin{array}{l}0.083 \\
(0.086)\end{array}$ & $\begin{array}{l}0.103 \\
(0.090)\end{array}$ & & $\begin{array}{l}0.112 \\
(0.098)\end{array}$ & $\begin{array}{l}0.109 \\
(0.094)\end{array}$ & & $\begin{array}{l}0.031 \\
(0.084)\end{array}$ & $\begin{array}{l}0.038 \\
(0.086)\end{array}$ \\
\hline Interesting work & & $\begin{array}{l}0.082 \\
(0.086)\end{array}$ & $\begin{array}{l}0.099 \\
(0.093)\end{array}$ & & $\begin{array}{l}0.006 \\
(0.061)\end{array}$ & $\begin{array}{l}-0.023 \\
(0.057)\end{array}$ & & $\begin{array}{l}0.054 \\
(0.042)\end{array}$ & $\begin{array}{l}0.034 \\
(0.053)\end{array}$ & & $\begin{array}{l}0.042 \\
(0.091)\end{array}$ & $\begin{array}{l}0.059 \\
(0.097)\end{array}$ \\
\hline Task knowledge & & $\begin{array}{l}0.004 \\
(0.079)\end{array}$ & $\begin{array}{l}-0.022 \\
(0.082)\end{array}$ & & $\begin{array}{l}0.0061 \\
(0.056)\end{array}$ & $\begin{array}{l}0.053 \\
(0.055)\end{array}$ & & $\begin{array}{l}0.024 \\
(0.097)\end{array}$ & $\begin{array}{l}-0.095 \\
(0.104)\end{array}$ & & $\begin{array}{l}0.235^{* * * *} \\
(0.093)\end{array}$ & $\begin{array}{l}0.170^{* * *} \\
(0.082)\end{array}$ \\
\hline
\end{tabular}




\begin{tabular}{|c|c|c|c|c|c|c|c|c|c|c|c|c|c|}
\hline \multicolumn{14}{|c|}{ Traditional vs secular-rational } \\
\hline \multirow{2}{*}{\multicolumn{4}{|c|}{ Confidence in church }} & $0.108 * * *$ & & & $0.131 * * *$ & & & $0.124 * * *$ & & & $0.173 * * *$ \\
\hline & & & & $(0.035)$ & & & $(0.045)$ & & & $(0.048)$ & & & $(0.059)$ \\
\hline \multirow{2}{*}{\multicolumn{4}{|c|}{ Divorce is never justifiable }} & 0.029 & & & $0.120^{* * *}$ & & & 0.021 & & & 0.051 \\
\hline & & & & $(0.044)$ & & & $(0.023)$ & & & $(0.035)$ & & & $(0.062)$ \\
\hline \multirow{2}{*}{\multicolumn{4}{|c|}{$\begin{array}{l}\text { Always love and respect one's } \\
\text { parents }\end{array}$}} & $0.067 *$ & & & $0.098^{* * * *}$ & & & $0.153^{* * *}$ & & & $0.100 * *$ \\
\hline & & & & $(0.037)$ & & & $(0.034)$ & & & $(0.040)$ & & & $(0.040)$ \\
\hline \multirow{2}{*}{\multicolumn{4}{|c|}{ Believes in hell }} & -0.017 & & & -0.023 & & & 0.0003 & & & 0.014 \\
\hline & & & & $(0.043)$ & & & $(0.047)$ & & & $(0.035)$ & & & $(0.059)$ \\
\hline \multicolumn{14}{|c|}{ Survival vs self-expression } \\
\hline \multirow{2}{*}{\multicolumn{4}{|c|}{$\begin{array}{l}\text { Homosexuality is never } \\
\text { justifiable }\end{array}$}} & $0.121 * * *$ & & & 0.006 & & & $0.163 * * *$ & & & -0.006 \\
\hline & & & & $(0.042)$ & & & $(0.037)$ & & & $(0.051)$ & & & $(0.064)$ \\
\hline \multirow{2}{*}{\multicolumn{4}{|c|}{$\begin{array}{l}\text { Tolerance and respect are } \\
\text { unimportant to teach at home }\end{array}$}} & $0.080 * * *$ & & & 0.020 & & & 0.005 & & & -0.016 \\
\hline & & & & $(0.025)$ & & & $(0.032)$ & & & $(0.021)$ & & & $(0.027)$ \\
\hline \multirow{2}{*}{\multicolumn{4}{|c|}{ Would never sign a petition }} & $0.123 * * *$ & & & $0.052 * * *$ & & & $0.071 * *$ & & & -0.005 \\
\hline & & & & $(0.032)$ & & & $(0.019)$ & & & $(0.034)$ & & & $(0.044)$ \\
\hline \multirow{2}{*}{\multicolumn{4}{|c|}{$\begin{array}{l}\text { Have to be careful when } \\
\text { trusting people }\end{array}$}} & -0.024 & & & $-0.082 * *$ & & & -0.063 & & & -0.005 \\
\hline & & & & $(0.032)$ & & & $(0.032)$ & & & $(0.043)$ & & & $(0.049)$ \\
\hline \multirow{2}{*}{\multicolumn{4}{|c|}{$\begin{array}{l}\text { Child needs both parents to be } \\
\text { happy }\end{array}$}} & 0.043 & & & $-0.055^{*}$ & & & 0.049 & & & 0.030 \\
\hline & & & & $(0.028)$ & & & $(0.032)$ & & & $(0.037)$ & & & $(0.036)$ \\
\hline \multirow[t]{20}{*}{ When job satisfact } & $1=1$ & $-3.842 * *$ & $-2.858^{* * *}$ & $-2.784 * *$ & $-5.581 * *$ & $-4.309^{* * *}$ & $-4.099 * *$ & $-5.435 * *$ & $-4.458^{* *}$ & $-4.601 * *$ & $-5.722^{* *}$ & $-3.993 * *$ & $-4.159^{* *}$ \\
\hline & & $(0.317)$ & $(0.279)$ & $(0.344)$ & $(0.518)$ & $(0.658)$ & $(0.724)$ & $(0.295)$ & $(0.414)$ & $(0.370)$ & $(0.483)$ & $(0.611)$ & $(0.647)$ \\
\hline & $=2$ & $-2.473 * *$ & $-1.497 * *$ & $-1.369 * *$ & $-3.854 * *$ & $-2.547 * *$ & $-2.356^{* * *}$ & $-4.557 * *$ & $-3.577 * *$ & $-3.787 * *$ & $-4.676^{* *}$ & $-2.966^{* *}$ & $-3.047 * *$ \\
\hline & & $(0.331)$ & $(0.243)$ & $(0.302)$ & $(0.215)$ & $(0.258)$ & $(0.292)$ & $(0.443)$ & $(0.446)$ & $(0.403)$ & $(0.366)$ & $(0.430)$ & $(0.417)$ \\
\hline & $=3$ & $-1.874 * *$ & $-0.894 * *$ & $-0.751 * *$ & $-3.192 * *$ & $-1.829^{* * *}$ & $-1.569^{* *}$ & $-3.939 * *$ & $-2.949 * *$ & $-3.125 * *$ & $-3.877 * *$ & $-2.122 * *$ & $-2.206 * *$ \\
\hline & & $(0.286)$ & $(0.227)$ & $(0.274)$ & $(0.221)$ & $(0.290)$ & $(0.357)$ & $(0.425)$ & $(0.434)$ & $(0.406)$ & $(0.361)$ & $(0.427)$ & $(0.419)$ \\
\hline & $=4$ & $-1.319 * *$ & -0.279 & -0.107 & $-2.450 * *$ & $-1.039 * *$ & $-0.815^{* *}$ & $-3.380 * *$ & $-2.342 * *$ & $-2.528 * *$ & $-3.207 * *$ & $-1.415^{* *}$ & $-1.467 * *$ \\
\hline & & $(0.285)$ & $(0.255)$ & $(0.320)$ & $(0.171)$ & $(0.260)$ & $(0.326)$ & $(0.448)$ & $(0.472)$ & $(0.432)$ & $(0.343)$ & $(0.403)$ & $(0.389)$ \\
\hline & $=5$ & $-0.628 * *$ & $0.501 * *$ & $0.656^{* * *}$ & $-1.772 * *$ & -0.288 & -0.078 & $-2.681 * *$ & $-1.580^{* * *}$ & $-1.789 * *$ & $-2.581^{* * *}$ & -0.721 & $-0.789 * *$ \\
\hline & & $(0.267)$ & $(0.235)$ & $(0.313)$ & $(0.164)$ & $(0.274)$ & $(0.358)$ & $(0.445)$ & $(0.461)$ & $(0.420)$ & $(0.336)$ & $(0.409)$ & $(0.400)$ \\
\hline & $=6$ & 0.021 & $1.275^{* *}$ & $1.448 * *$ & $-1.085^{* *}$ & 0.506 & $0.683^{* * *}$ & $-1.943^{* *}$ & -0.752 & $-0.944 * *$ & $-1.928 * *$ & 0.029 & -0.041 \\
\hline & & $(0.265)$ & $(0.270)$ & $(0.344)$ & $(0.164)$ & $(0.265)$ & $(0.342)$ & $(0.454)$ & $(0.473)$ & $(0.441)$ & $(0.315)$ & $(0.392)$ & (0.384) \\
\hline & $=7$ & $0.689 * *$ & $2.056 * *$ & $2.247 * *$ & $-0.413 * *$ & $1.295 * *$ & $1.490 * *$ & -1.092 & -0.217 & 0.059 & $-1.106^{* *}$ & $0.986^{* *}$ & $0.897 * *$ \\
\hline & & $(0.259)$ & $(0.261)$ & $(0.336)$ & $(0.178)$ & $(0.277)$ & $(0.361)$ & $(0.427)$ & $(0.439)$ & $(0.390)$ & $(0.322)$ & $(0.434)$ & $(0.437)$ \\
\hline & $=8$ & $1.614 * *$ & $3.094 * *$ & $3.319^{* *}$ & $0.532 * *$ & $2.394 * *$ & $2.596^{* *}$ & -0.016 & $1.423 * *$ & $1.323 * *$ & -0.013 & $2.279 * *$ & $2.204 * *$ \\
\hline & & $(0.262)$ & $(0.249)$ & $(0.319)$ & $(0.191)$ & $(0.301)$ & $(0.401)$ & $(0.432)$ & $(0.441)$ & $(0.392)$ & $(0.345)$ & $(0.481)$ & $(0.487)$ \\
\hline & $=9$ & $2.585^{* *}$ & $4.187 * *$ & $4.404 * *$ & $1.630^{* *}$ & $3.627 * *$ & 3.830 ** & $1.029^{* * *}$ & $2.568 * *$ & $2.475 * *$ & 1.241 ** & $3.650^{* *}$ & $3.598 * *$ \\
\hline & & $(0.275)$ & $(0.300)$ & $(0.361)$ & $(0.165)$ & $(0.306)$ & $(0.378)$ & $(0.471)$ & $(0.477)$ & $(0.418)$ & $(0.336)$ & $(0.501)$ & $(0.515)$ \\
\hline & $=10$ & $4.327 * *$ & $5.926 * *$ & $6.066^{* *}$ & $3.065^{* *}$ & $5.113 * *$ & $5.358 * *$ & $2.833 * *$ & $4.482 * *$ & $4.281 * *$ & $2.986 * *$ & $5.440 * *$ & $5.396 * *$ \\
\hline & & $(0.442)$ & $(0.362)$ & $(0.405)$ & $(0.334)$ & $(0.449)$ & $(0.557)$ & $(0.534)$ & $(0.491)$ & $(0.513)$ & $(0.573)$ & $(0.716)$ & $(0.753)$ \\
\hline Pseudo R-square & & 0.006 & 0.061 & 0.064 & 0.003 & 0.056 & 0.060 & 0.004 & 0.049 & 0.054 & 0.003 & 0.059 & 0.061 \\
\hline Sample size & & 5363 & 4597 & 3128 & 7845 & 7445 & 5295 & 6348 & 6043 & 4309 & 6281 & 5983 & 4868 \\
\hline
\end{tabular}

Note: Standard errors adjusted for clusters of country affiliations. Control variables: Female, Non-married or widowed, Low household income, Full time, Professional.

$* * *, * *$, and $*$ denotes significance at $1 \%, 5 \%$ and $10 \%$ levels, respectively.

The models were re-estimated using z-score transformations of ordered categories and revealed qualitatively similar results. 
Table 4. Odds ratios of cultural values

\begin{tabular}{|c|c|c|c|c|}
\hline Variable & 1981 & 1990 & 1999 & 2008 \\
\hline \multicolumn{5}{|l|}{ Traditional vs secular-rational } \\
\hline Confidence in church & $1.114 * * *$ & $1.140 * * *$ & $1.132 * * *$ & $1.188 * * *$ \\
\hline Divorce is never justifiable & 1.029 & $1.128 * * *$ & 1.021 & 1.052 \\
\hline Always love and respect one's parents & $1.069^{*}$ & $1.103 * * *$ & $1.165 * * *$ & $1.106 * *$ \\
\hline Believes in hell & 0.983 & 0.977 & 1.000 & 1.014 \\
\hline \multicolumn{5}{|l|}{ Survival vs self-expression } \\
\hline Homosexuality is never justifiable & $1.128 * * *$ & 1.006 & $1.177 * * *$ & 0.994 \\
\hline Tolerance and respect are unimportant to teach at home & $1.083 * * *$ & 1.020 & 1.005 & 0.984 \\
\hline Would never sign a petition & $1.130 * * *$ & $1.053 * * *$ & $1.074 * *$ & 0.995 \\
\hline Have to be careful when trusting people & 0.976 & $0.921 * *$ & 0.939 & 0.995 \\
\hline Child needs both parents to be happy & 1.044 & $0.946^{*}$ & 1.050 & 1.030 \\
\hline Pseudo R-square & 0.064 & 0.060 & 0.054 & 0.061 \\
\hline Sample size & 3128 & 5295 & 4309 & 4868 \\
\hline
\end{tabular}

Note: All socio-demographic and work-related characteristics also included, but not reported here. $* * *, * *$, and $*$ denote significance at $1 \%, 5 \%$ and $10 \%$ levels, respectively.

Odds ratios are presented to aid interpretation of the effects of all variables on job satisfaction.

'Confidence in church' and 'always love and respect one's parents' can be interpreted accordingly. However, interpretation of odds-ratio magnitudes for the other cultural values should be strongly discouraged due to their construction using the orthogonalisation process.

\section{Biographies}

Gail Pacheco is Associate Professor of Economics, and Co-Director of the NZ Work Research Institute at Auckland University of Technology. Her research interests lie in applied economics and labour market policy. She is also Editor-in-Chief of New Zealand Economic Papers. Her recent publications include work in Social Science \& Medicine, Work, Employment \& Society, and Review of Income \& Wealth.

De Wet van der Westhuizen is a Doctoral candidate at Auckland University of Technology (AUT), New Zealand. His research interests are focussed in the area of Labour Economics, and include participative decision making and job satisfaction. More recently his attention has moved towards investigating minimum wage impacts on youth. De Wet has been the recipient of numerous awards/scholarships, including the AUT Vice Chancellor's Doctoral Scholarship 2015.

Abby Ghobadian is professor of Management at Henley Business School. His research interests lie in understanding and identifying factors that contribute to organisations competitiveness. He has published over 100 peer reviewed articles in top journals, 8 research monographs, a text book, and numerous book chapters as well as conference contributions and contributions to popular/practitioner publications. Abby has received many research grants and supervised more than 25 doctoral students to completion. He has served on a number of government working parties and was a member the APPG Commission on the future of management and leadership that produced a well-received report in July 2014. Abby is the Past President of the British Academy of Management, serves on the Chartered Management Institute's (CMI) Academic Advisory Council, as well as editorial boards of a number of international journals. He is a Fellow of the Academy of Social Sciences, Fellow of the British Academy of Management, Companion of Charted Management Institute, 
recipient of an honorary doctorate from University of Pecs, and co-editor of Journal of Strategy and Management.

Don J. Webber is Professor of Applied Economics at the University of the West of England, Bristol. His research interests lie in the connections between health, education, productivity and geography and has written over 80 published academic articles. He also regularly produces consultancy research for a variety of organisations, such as the Welsh Government, AHRC, Joseph Rowntree Foundation and LEPs. He is on the editorial board for Research into Post-Compulsory Education and is an active member of the Regional Science Association International and the Regional Studies Association.

Nicholas O'Regan is Associate Dean [Research and Innovation] and Professor of Strategy/Enterprise and Innovation at the University of the West of England, Bristol. His research interests lie in strategic issues, technology deployment and operational effectiveness. $\mathrm{He}$ is co-editor of the Journal of Strategy and Management, and the Journal of Family Business Management. He has published in numerous international journals and is on the editorial board for journals such as Technovation. Nicholas was elected a Fellow of the Academy of Social Sciences in 2011. 


\section{Endnotes}

1 The framework presented by Hofstede (1991) includes the following dimensions: (i) power distance, (ii) uncertainty avoidance, (iii) individualism vs collectivism, (iv) masculinity vs femininity, and (v) long-term orientation vs short-term orientation.

2 'Confidence in church' is a specific variable in the European Values Study (EVS, 2014) and it has a high level of religious relevance for European countries. Its degree of relevance would be lower in other parts of the world where many do not refer to 'the church', as in parts of Asia, and future research that applies our approach to other parts of the world could parameterise this type of religiosity in other location-specific ways. 